\title{
Monotheism (From a Sociopolitical and Economic Perspective)
}

\author{
Murat Iyigun \\ CID Working Paper No. 151 \\ October 2007 (Revised December 2007)
}

(C) Copyright 2007 Murat Iyigun and

the President and Fellows of Harvard College

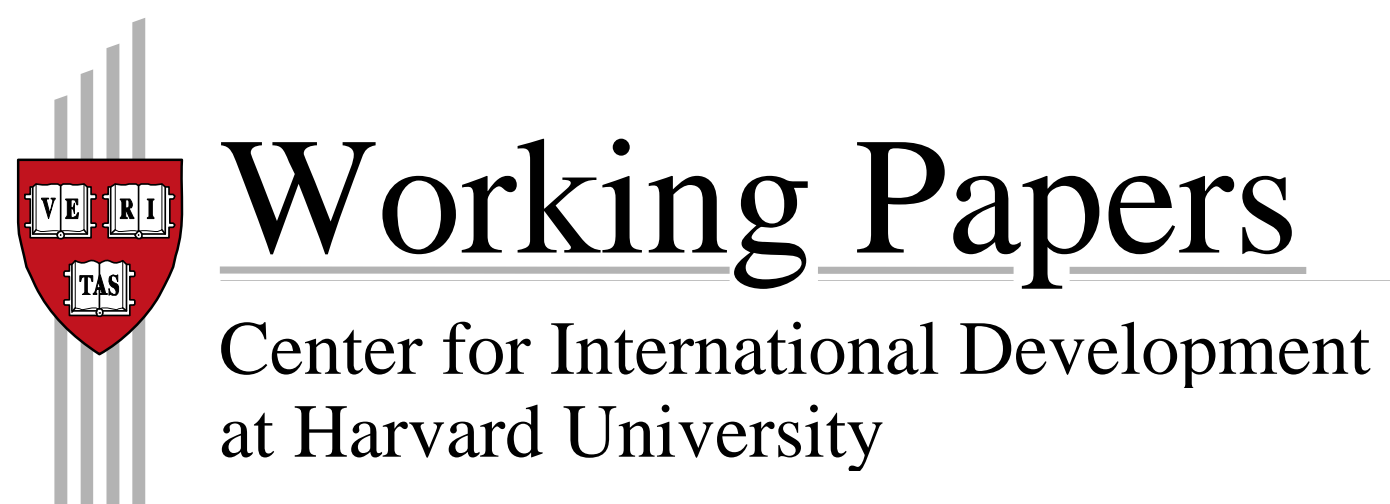




\title{
Monotheism (From a Sociopolitical and Economic Perspective)
}

\author{
Murat Iyigun
}

\begin{abstract}
The Axial Age, which lasted between 800 B. C. E. and 200 B. C. E., covers an era in which the spiritual foundations of humanity were laid simultaneously and independently in the various geographic areas, and all three major monotheisms of Judaism, Christianity and Islam were born between 606 B. C. E. and 622 C. E. in the Middle East. In this paper, I offer a taxonomy to comprehensively characterize the impact of monotheism on early economic development. Monotheist religions produced a paradigm shift in sociopolitical institutions because they (a) involve a strong degree of increasing returns to scale and the natural monopoly powers commensurate with it, (b) not only personalize the spiritual exchange relationship between the individual and the one deity, but also, due to the fact that this relationship extends into the afterlife as well, enhance individual accountability, and (c) expand their adherents' time horizon beyond biological life and impact the time discount between one's lifetime and the after-life. Taken together, these features suggest that the spread of monotheism ought to have promoted sociopolitical stability. Utilizing original historical data between 2500 B. C. E. and 1750 C. E. on 232 limited access orders, such as dynasties, kingdoms and empires. I show that monotheism had a positive and statistically significant impact on the length of reign as well as the average geographical size of social orders. Thus, I find empirical evidence that the birth and adoption of monotheistic religions aided early development both in the West and the Near East until the advent of the Industrial Revolution.
\end{abstract}

Keywords: economic development, religion, institutions

JEL codes: C72, D74, N33, N43, O10 
October 2007

\title{
MONOTHEISM \\ (From a Sociopolitical \& Economic Perspective)
}

\author{
Murat Iyigun*
}

\begin{abstract}
The Axial Age, which lasted between 800 B. C. E. and 200 B. C. E., covers an era in which the spiritual foundations of humanity were laid simultaneously and independently in various geographic areas. And all three major monotheisms of Judaism, Christianity and Islam were born between 606 B. C. E. and 622 C. E. in the Middle East. In this paper, I offer a taxonomy to comprehensively characterize the impact of monotheism on early economic development. Monotheist religions produced a paradigm shift in sociopolitical institutions because they (a) involve a strong degree of increasing returns to scale and the natural monopoly powers commensurate with it, (b) not only personalize the spiritual exchange relationship between the individual and the one deity, but also, due to the fact that this relationship extends into the afterlife as well, enhance individual accountability, and (c) expand their adherents' time horizon beyond biological life and impact the time discount between one's lifetime and the after-life. Taken together, these features suggest that the spread of monotheism ought to have promoted sociopolitical stability. Utilizing historical data between 2500 B. C. E. and 1750 C. E. on 232 limited access orders, such as dynasties, kingdoms and empires, I show that monotheism had a positive and statistically significant impact on the length of reign as well as the average geographical size of social orders. Thus, I find empirical evidence that the birth and adoption of monotheisms aided early development in the West, the Near East and even parts of Africa until the advent of the Industrial Revolution.
\end{abstract}

Keywords: Economic Development, Religion, Institutions. JEL Classification Numbers: C72, D74, N33, N43, O10.

\footnotetext{
* University of Colorado, CID at Harvard University and IZA. This paper began to take shape when I was visiting the Center for International Development (CID). I especially thank Ricardo Hausmann and Dani Rodrik for their encouragement and hospitality. For comments and suggestions, I also thank Naci Mocan and Ann Owen. All errors and speculations are mine alone. Please send all correspondence to Murat Iyigun, University of Colorado at Boulder, Department of Economics, Campus Box 256, Boulder, CO 80309-0256. E-mail: murat.iyigun@colorado.edu or murat_iyigun@ksg.harvard.edu. Phone: (303) 492-6653. Fax: (303) 492-8622.
} 


\section{"If God does not exist, all is permitted."}

Ivan in The Brothers Karamazov (1880), Fyodor Dostoyevsky.

\section{Introduction}

The spiritual foundations of human societies were laid in various different geographic regions of the world fairly simultaneously during what is defined as the Axial Age, which lasted between 800 B. C. E. and 200 B. C. E. ${ }^{1}$ All three major monotheisms were born around this age between 606 B. C. E. and 622 C. E. in the Middle East and they spread fairly rapidly to Europe, Africa and Asia subsequently. By the year 2000, 161 countries subscribed predominantly to one or more of the three monotheistic faiths, representing 86 percent of the 188 countries for which data exist and close to 3.3 billion people or roughly 55 percent of the world population. In the words of Diamond (1997, pp. 266-67), "At the end of the last Ice Age, much of the world's population lived in [hunter-gatherer societies] and no people then lived in a much more complex society. As recently as 1500 A. D., less than 20 percent of the world's land area was marked off by boundaries into states run by bureaucrats and governed by laws. Today, all land except Antarctica's is so divided. Descendants of those societies that achieved centralized government and organized religion earliest ended up dominating the modern world. The combination of government and religion functioned, together with germs, writing, and technology, as one of the four main sets of proximate agents leading to history's broadest pattern."

Sociologists and political scientists have long been intrigued by how religion, governments and polities might have influenced each other historically. Various Enlightenment and early-20th century, post-Enlightenment scholars, such as David Hume, Auguste Comte, and Emile Durkheim, believed that faith and religion would experience an inevitable decline in the face of scientific and technological advances (see Hume, 1911, and Comte, 1855). But they also articulated in detail the social functions of faith and religion. According to Hume (1911), for example, benevolence and moral considerations associated with religion are the pillars of social harmony and stability. And Durkheim (1912) saw in group and social cohesion the manifestations of religious practices, norms and rituals. In the 1930s, the structural-functionalist school, led by Talcott Parsons began to assert that the cohesion of societies depended on their members sharing a common

\footnotetext{
${ }^{1}$ Term coined originally by Karl Jaspers (1953). See also Armstrong (2006, p. xvi).
} 
purpose, conceptions of morality and an identity. In this, they were adhering to Emile Durkheim who saw in religion these social necessities. The validity of this line of thought has been called into question more recently, mostly on account of countries like the United States which were and are able to sustain social cohesion as well as a national identity in conjunction with religious pluralism and tolerance. ${ }^{2}$ Still, the structural-functionalist concept can apply more generally at the level of not one particular faith but according to the (mono)theistic attribute of a plurality of faiths to which members of a society adhere. Along these lines, Stark (2001) has provided a sociological "theory of Gods" in which he identifies personalized supernatural exchange relations and otherworldly rewards as two features of monotheism that impact social organization and sociopolitical stability. In contrast, economists have been fairly mute on this issue despite the fact that Adam Smith had a section in The Wealth of Nations (1776) devoted to how religious affiliation or lack thereof could impact national and political stability via its influence on conflict and cooperation. ${ }^{3}$

In this paper, I argue that the birth of monotheism was a major breakthrough in sociopolitical organization and that it had a returns to scale advantage relative to paganist and polytheist religious traditions. That is, monotheist religions involve a strong degree of increasing returns to scale and the natural monopoly powers commensurate with it. Second, monotheistic faiths are unique in that they not only personalize the spiritual exchange relationship between the individual and the one deity, but due to the fact that this relationship extends into the afterlife as well, they also enhance individual accountability. On that basis, monotheistic faiths expand their adherents' time horizon beyond biological life and impact the time discount between one's lifetime and the afterlife.

There are two implications of these features: First, due to the fact that institutions of monotheism possessed the ecclesiastical monopoly power to legitimize or undermine the temporal powers of the political elite, they helped produce political and ecclesiastical institutions that were powerful. In particular, religious organizations derived substantial financial and political benefits from being associated with One God. Thus, the stability of civilizations came to be linked with their respective ecclesiastical institutions. Second, the fact that all monotheist religions hold individuals accountable to God on Judgment Day aided contract enforcement, commitment and respect for private property within social orders. The combination of this accountability with the stronger emphasis on the afterlife also complemented military technologies in external conflicts. Both of these

\footnotetext{
${ }^{2}$ For more details, see Stark (2001, p. 245).

${ }^{3}$ Stark, 2001, p. 116.
} 
observations then imply, in Durkheimian fashion, that monotheist civilizations ought to have endured longer and perhaps even controlled larger geographic domains. As a result, monotheistic faiths should have spread and grown at the expense of paganist and polytheist religions.

Utilizing data between 2500 B. C. E. and 1750 C. E. on 232 limited access orders, such as dynasties, kingdoms and empires, I show that the birth of Judaism, Christianity and Islam and adherence to monotheism had statistically significant effects on the length of reign as well as the average geographical size of civilizations historically. ${ }^{4}$ Specifically, I demonstrate below that kingdoms, dynasties and empires lasted about 340 years on average during this long time interval. And those historical civilizations that adopted monotheism, regardless of whether it was Judaism, Christianity, or Islam, lasted about 35 to 65 percent longer and had a 10 percent higher likelihood of surviving an extra century than non-monotheist social orders . Beyond the general impact of adherence to monotheism, I cannot find any empirical evidence that Judaism, Christianity or Islam exerted an impact on the length of reign of historical civilizations. I also confirm that monotheism had a roughly similar effect on the geographic domain over which historical civilizations reigned during their peak. That is, monotheist limited access orders controlled about twice the land area of their non-monotheist counterparts. Unlike the results on duration, however, I find some evidence that adherence to a specific religion - Islam — did exert an additional positive impact on geographic domain.

In the way of up-front clarification, one might be bound to think that, since One God faiths are built upon true revelations, they were destined to slowly wipe out the falsities of paganism, polytheism and the like. Be that as it may, such an assessment does not explain why monotheisms spread at the expense of other faiths at least partly due to the fact that monotheist societies lasted longer and spread wider. Put differently, monotheisms could have become the ecclesiastical norm among the historical societies of the Middle East, Africa, Europe and Asia without having had an effect on the duration and dominance of civilizations. But the role of monotheisms on empire's durability and dominance seems to have been an important reason why Christianity and Islam spread rapidly in Europe, North Africa and the Middle East between the 4th and 9th centuries.

This paper relates to a strand in economics that emphasizes religion, social norms and culture as important factors in individual behavior and/or social organization. The

\footnotetext{
${ }^{4}$ As I clarify below, I shall define a society as monotheist if a majority of its citizens adhered to one of the three main monotheist religions, and/or their government and political organizations promoted one of the three monotheist traditions through its social, economic and military policies. I shall also discuss some empirical issues that could complicate the analysis given this definition.
} 
main focus of some work in this strand is religion and culture in general (e.g., North, 1990, Iannaccone, 1992, Temin, 1997, Landes, 1999, Greif, 2006, Glaeser and Sacerdote, 2002, Jones, 2003, Fernandez et al. 2004, Fernandez, 2007, Barro and McCleary, 2003, 2005, Guiso, Sapienza and Zingales, 2003, forthcoming, and Spolaore-Wacziarg, 2005). Others in this line focus on a specific religion, such as Judaism, Islam or different denominations of Christianity to emphasize how individual behavior and the evolution of sociopolitical institutions were - and still are - driven by them (e.g., Botticini and Eckstein, 2005a, 2005b, Kuran, 2004b, 2005, Becker and Woessmann, 2007, Lewis, 2002). Due to its emphasis on the links between ecclesiastical institutions and early development, the work below is also related to the theoretical and empirical literatures on institutions and economic progress (e.g., North, 1990, North et al. 2007, Acemoglu et al. 2001, and Rodrik et al. 2004).

The remainder of this paper is organized as follows: In Section 2, I summarize the role of monotheism in socio-politics, economics and vice versa. In Section 3, I describe my data, present the empirical findings and check for robustness. In Section 4, I conclude.

\section{A Simple Taxonomy}

Although they are not exclusive to the three main monotheist traditions, there are at least three salient traits of One-God faiths which impact the economic and sociopolitical realms.

\subsection{Returns to Scale \& Natural Monopoly}

Judaism, Christianity and Islam all acknowledge and promote the "oneness" of God. By nature, this introduces monopoly power and a strong element of increasing returns to scale in the provision of religious services. The monopolization of faith is a defining characteristic of the three monotheistic traditions. Niebuhr (1932, p. 53) points out that "The omnipotence of God, as seen in the world of nature, invests his moral character with the quality of the absolute and transfigures it into holiness... The religious conscience is sensitive not only because its imperfections are judged in the light of the absolute but because its obligations are felt to be obligations toward a person. The holy will is a personal will."

Emphasizing a related point, Armstrong (1993, p. 49) identifies that monotheistic faiths were unique in their mutual exclusivity, especially with respect to the belief in one God. She states, "hostility toward other gods was a new religious attitude [of monotheism]. Paganism was an essentially tolerant faith: provided that the old cults 
were not threatened by the arrival of a new deity, there was always room for another god alongside the traditional pantheon. Even where the new ideologies of the Axial Age were replacing the old veneration of the gods, there was no such vitriolic rejection of the ancient deities."

Stark (2001, p. 19, 34) draws a critical distinction between the individual's relationship with one God under monotheism and that with multiple deities in polytheism, according to which competition between various divine beings played a role in shortening the interactions between the adherents and their gods:

"Polytheistic religions sustain only short-term exchanges, as humans seek specific and quite immediate benefits from the Gods and spread their risks by shopping around and patronizing multiple suppliers. If there is only one God, this necessitates an exclusive exchange relationship, there being no logical alternatives... It is illogical to deal with a flock of specialized Gods if there is One God of unlimited scope and capacity. An exclusive relationship with One God is also an extended relationship - usually lifelong. No longer are humans able to go "God shopping" or to pit one God against another. This results in extremely strong organizations possessed of immense resources, consistent with a God of unlimited power and concern."

Furthermore, monotheisms differ from one another in the extent to which they are 'clerical' or 'congregational' although, in this regard, the heterogeneity within Christianity - which for the most part is due to the Protestant Reformation and its offshoots — is unique. ${ }^{5}$ Naturally, the clerical system enabled more of a fusion between ecclesiastical authority and temporal political power. That is, the extent to which the clergy

\footnotetext{
${ }^{5}$ In Islam, which by construction is congregationalist, the Caliphate was at least at times used to legitimize political authority. During its early tenure, the Caliphate represented a powerful religious and political authority for both the Sunni and the Shi'a. According to Armstrong (1988, p. 585). "The Caliph was the successor and deputy of the Prophet Mohammed and he was recognized as the supreme authority of the Muslims by the Sunni until the Mongolian invasions in the late thirteenth century. According to the Sharia, the caliph exercised full authority in both spiritual and political matters, but in fact, his position was weak. After the period of the rashidun, the first four Rightly Guided Caliphs, and the rise of the sultans and amirs throughout the huge Islamic empire, the caliph lost credibility and became a figurehead."

Even during the later era, however, the Sunni Caliphate represented a medium of legitimizing political authority: the Ottoman Emperor Yavuz Sultan Selim conquered the Arabian peninsula in 1517 and assumed the Sunni Caliphate, a title which all the Ottoman Sultans carried until 1924 when the fledgling Turkish Republic abolished it.

In contrast, for the Shi'a, there were twelve Caliphs who possessed religious and political authority. According to Shi'a liturgy, the Prophet Mohammed wanted his cousin Ali to succeed the first Caliph, Abu Bakr. Thus, after rashidun (which represents the reign of the first four caliphs recognized as
} 
had ecclesiastical authority often influenced the political sphere because the clergy could use their powers to bolster or undermine the legitimacy of secular authorities. On this, Niebuhr (1932, pp. 6-7) notes "The two most obvious types of power are the military and the economic, though in primitive society the power of the priest, partly because he dispenses supernatural benefits and partly because he establishes public order by methods less arduous than those of the soldier, vies with that of the soldier and the landlord."

These increasing returns and the associated powers of monopoly are what help to explain the prominent monopoly roles of the Roman Catholic Church in Western Europe during the common era, the Greek Orthodox Church in Eastern Europe between 4 th century and the 19th centuries C. E., as well as that of the Caliphate in the Rashidun era, Ummayad and Abbasid dynasties between 600 C. E. and 900 C. E. and the Ottoman Empire between 1517 and 1924. As Stark explains the fact that individuals are held accountable by one God for their temporal deeds and that his rewards are often delayed until after death, "is a major factor allowing Godly religions to generate the long-term levels of commitment necessary to sustain strong religious organizations."

\subsection{Personalized Spiritual Exchange and Accountability}

Human spirituality is pillared on the desire to grasp the meaning of existence and rationalize, at least to an extent, natural phenomena that are incomprehensible to the human mind. With atheistic spiritual movements, explanations of such phenomena typically involve supernatural powers that do not have the conscious will that is required for personalized involvement and communication. With polytheistic faiths, there are multiple deities who rule various aspects of temporal life, but there exists none with the omnipotence to control all aspects of temporal and spiritual existence. In contrast, monotheistic faiths involve one omnipotent divine being who has not only control over the whole universe, but also desires he wishes humans to fulfill which he can communicate them.

Stark (2001, p. 15-19) observes that, by personalizing the spiritual exchange and reenforcing accountability, theology and faith provide a very effective means to deal with human wants and desires that are often fleeting and inherently in short supply, such as survival, health, financial security, etc.:

"Because Gods are conscious beings, they are potential exchange part-

legitimate by both the Sunni and the Shi'a), the descendants of Ali began to offer an alternative rule to the Sunni caliphs. When Ali's bloodline died out after the twelfth Caliph, the Shi'a declared that he would eventually return as their Messiah. 
ners because all beings are assumed to want something for which they might be induced to give something valuable. Indeed, the core of Godly religious doctrines consists of explanations about what Gods want and what one must do to earn their blessings... That is, Godly religions assume that divine beings not only have desires they wish humans to fulfill, but that they can communicate them... If theology, in effect, tells us what God wants, it is equally important that we understand the other side of this exchange relationship: what do people want from God? To answer, we must acknowledge the most fundamental aspect of the human predicament, namely that rewards are always in limited supply and some are entirely unavailable... In response, humans tend to seek alternative means to overcome limited supplies or complete unavailability, [such as miracles and otherworldly rewards.]"

By nature, otherworldly rewards are compensation for individuals' temporal deeds and, to an extent, they substitute for temporal needs and wants that are in limited supply or that are entirely unavailable.

\subsection{Time Horizon \& Time Discounting}

The belief in afterlife is not unique to monotheist traditions but, the Judgement Day, when individuals are held accountable for their deeds and are judged by God accordingly, is a central tenet of all three major monotheist traditions. This is typically lacking in religions that involve reincarnation.

In Jewish liturgy there is significant prayer and talk of a "book of life" that one is written into, indicating that God judges each person each year even after death. This annual judgment occurs on Rosh Hashanah. In Christianity, the Last Judgment or Day of the Lord is the simultaneous judgment of every person when, after the resurrection of the dead, Christ will return to judge the living and the dead. Those positively judged will be saved and live in God's presence in Heaven and those who are negatively judged will be cast to eternal Hell. In Islam, the Day of Judgment is described in the Quran and the Hadith. The Islamic Judgment day starts 30 years before the end of the earth, and sees the return of prophet Jesus to the earth. The last 30 years on earth will be a line of events that will see the resurrection of the deceased. This is followed by judgment day beyond the universe involving Hell and Heaven and the weighing of Good and Evil.

In contrast, religions that include reincarnation (e.g., Hinduism) lack a Day of Judgment; the determination of how an individual is to be reborn being a particular judgment on the merit of the life just lived. 
For our purposes, then, we can categorize the various effects of a personalized spiritual exchange between the individual and God in addition to the belief in the afterlife and the Judgement Day according to whether they are intra-social or extra-social in nature.

\subsection{Intra-Social Effects}

Scholars of theology, psychology, sociology and, to some extent, economics too have recognized the moral, ethical and egalitarian aspects of religion, in general, and monotheist traditions, in particular.

For example, while being dismissive of religion in general and arguing that it belonged to relatively primitive states of social order, such as the pre-Industrial era, Sigmund Freud recognized that it promoted ethical values and moral codes essential to a society's functioning. Karl Marx, who also had no room for faith in his vision of socialism, stated that it was "the opium of the people, which made this suffering bearable." According to Armstrong (1993, p. 48) "It has to be said that this imaginative portrayal of God in human terms has inspired a social concern that has not been present in Hinduism. All three of the God-religions have shared the egalitarian and socialist ethic of Amos and Isaiah. The Jews would be the first people in the ancient world to establish a welfare system that was the admiration of their pagan neighbors." Along the same lines, Farrington (2002) notes that, while for some empires religion was the main impetus for their existence, for most of them it served as a means of social stability and control.

With respect to the impact of each monotheist religion on its adherent societies, the economic history literature is fairly well-developed with regard to the impact of various Christian denominations - in particular, those of the Protestant Reformation and its offshoots - on the European economic takeoff. Moreover, in recent years, there has been a fledgling body of work which has begun to focus on the link between faith-related institutions and economic development within Jewish and Muslim societies.

As is very well known, the impact of Protestantism on European sociopolitical and economic evolution has been extensively debated. The origins of this debate can be traced back to Weber (1930) who subscribed to the view that Protestantism - particularly its offshoot Calvinism — had "cultivated an intense devotion to one's work or 'calling' in order to assure oneself that one had in fact been selected for salvation." Rosenberg and Birzdell (1986, p. 129) are sympathetic to this view and discuss it in detail. But various scholars dispute it strongly. For instance, Mokyr (1990 and 2002) dismisses this link by noting that the Counter-Reformation era was probably as bigoted a period as the pre-Reformation era. 
One of the main thrusts of Martin Luther was his emphasis on the laity's responsibility to study and personally examine the Scripture for themselves. As such, Protestantism had two discernible, long-term effects on the European society and its organization. First, it clearly empowered the individual and emphasized his personal responsibility as superior over ecclesiastical regulations and regimentations (see Hillerbrand, 1968, p. xxiv). Second, the Lutheran calls for individuals to study and read the Bible themselves spurred a greater emphasis on literacy as well as various interpretations of the Scripture with the translation and the printing of the Bible in the vernacular instead of its original Latin.

This last point is emphasized by Becker and Woessmann (2007) who find empirical support for the idea that the Protestant Reforms spurred human capital accumulation among the followers of the Protestant reformers. In expounding on this idea, Hillerbrand (1968) notes that about one million copies of Luther's tracts had been published by 1523 and that the literature produced by the Reformation scholarship — led by the preeminent figures of the time such as Luther, Zwingli and Calvin as well as other minor reformers such as Bucer, Melanchthon and Carlstadt — would not have been published had there not been sufficient demand.

Botticini and Eckstein $(2005,2007)$ make this same argument with respect to Judaism: the reading of the Torah and the Talmud became a requirement of Judaism following the burning of the Jewish Temple in Jerusalem in 64 C. E., thereby leading to advanced literacy and a steep path of human capital accumulation in the Jewish communities of the Middle East between 64 C. E. and 200 C. E.

Others have emphasized that perhaps the most important legacy of the recognition of Protestantism and its various offshoots by the Catholic Church in the 16th century was greater social cohabitation in Europe (see, MucColloch, 2003, p. 652).

With regard to Islam, Armstrong (1993) and Lewis (2003) discuss in some detail various institutional features of Islam and the impact of the latter on ancient Arab civilizations, such as the Abbasids, Umayyads, and Mamluks. Kuran (2004a, 2004b) and Lewis (2002) also elaborate on how Islam and its interactions with Christianity and Judaism influenced the institutions of the Ottoman Empire. The common thread among these works is that the Islamic culture helped promote stability in social, political and the economic realms, although in the case of the Ottoman Empire some of the very institutional traits that promoted stability came at the cost of dynamic flexibility.

\subsection{Extra-Social Effects}

There is a well-established strand in the political science literature that focuses on reli- 
gion in explaining the historical patterns of violent conflict and cooperation; it shows that differences in religious beliefs have historically induced violent conflicts. For instance, in compiling a data set with over 300 violent conflicts around the world between 1820 and 1949, Richardson (1960) reveals that differences of religion, especially those of Christianity and Islam, have been causes of wars and that, to a weaker extent, "Christianity incited war between its adherents." In addition, Richardson finds that war alliances had subdued and prevented wars between former allies, although this influence declined with the passage of time since the alliance. As Wilkinson (1980) points out, Richardson's analysis applies more broadly in the sense that "the propensity of any two groups to fight increases as the differences between them (in language, religion, race, and cultural style) increase."

The fall of Jerusalem to Islamic civilizations instigated (depending on how you count, about nine) Holy Crusades that had a profound impact on how the Christian, Muslim and Jewish civilizations interacted subsequently. With reference to the confrontations of Ottomans and Europeans, in particular, Faroqhi (2004, pp. 41-42) notes "these rivalries did not prevent Christians from both western and south-eastern Europe from seeing themselves as belonging to one and the same religion, and this sentiment was especially strong when they were confronted with a Muslim ruler." And in a companion paper, Iyigun (2006), I have shown how the conflict between the Muslim Ottoman Empire and European secular and ecclesiastical powers aided and abetted Protestants' rise. Such evidence lends further credence to the arguments that religious affiliation has historically been a key determinant of international conflicts and cooperation.

Niebuhr (1932, pp. 65-66) accepts that stoking patriotic notions of identity was important for galvanizing a society in external conflicts too. But what made religion especially effective as a complementary component of national defense was the "absolute" nature of its claims, rewards and punishments:

"It is not only religion which gives a special dignity and worth to the life of the nation to which one belongs. Patriotism is a form of piety which exists partly through the limitation of the imagination, and limitation may be expressed by savants as well as by saints. The wise men of the nations were just as sedulous in proving, during the late Word War, that their particular nation had a peculiar mission to "culture" and "civilization" as were the religious leaders in asserting that the will of God was being fulfilled in the policy of their state. But since the claims of religion are more absolute than those of any secular culture the danger of sharpening the self-will of nations 
through religion is correspondingly greater."

Stark (2001, p. 35) in fact ties this aspect of monotheism to its more benign forms, such as its adherents extensive missionary zeal and desire to spread the word of one true God:

"When we examine history, we find no massive mobilizations on behalf of the Gods. Polytheistic societies are capable of prodigies of effort including those of conquest. But the armies of Rome, imperial China, or ancient Egypt did not march on behalf of divine will — unlike the armies of Islam or those enlisted by popes for Crusades to the Holy Land. Granted, many Christian crusaders and Islamic conquerors also had nonreligious motives, and some may even have been irreligious. But, lacking the powerful religious justification of doing God's Will, these events would not have taken place. Only One True God can generate great undertakings out of primarily religious motivations, chief among these is the desire, indeed the duty, to spread the knowledge of the One True God..."

\section{The Empirical Analysis}

\subsection{Data Sources, Descriptions \& Classifications}

Testing the theory of monotheism I outlined above, in particular, the idea that monotheism produced sociopolitical stability, requires establishing specifically what is meant by a monotheist society. Thus, for practical purposes, I shall define a society as monotheist if a majority of its citizens adhered to one of the three main monotheist religions and/or its government and political organizations promoted one of the three monotheist traditions through their social, economic and military policies.

One potential objection to our definition could be that it treats all individuals of a given society identically. But as we clearly know, there exists a great deal of heterogeneity in the individuals' degree to which they adhered to and practiced the majority monotheism of their society. Even in the case of forced conversions following conquest and subversive campaigns, there was no guarantee that the converts practiced the dictated state monotheism.

A relevant example in this regard is the plight of the Jewish converts in al-Andalus prior and subsequent to the pogroms of 1391. The conversion of many Jews (the conversos) during this era in order to avoid massacre in Christian hands was not enough to quell suspicions that they were in fact 'closet Jews' and those coreligionists who dared 
not to have converted were also promoting Judaism at the expense of Christianity. Thus began the infamous Spanish Inquisition which was the design of Ferdinand of Aragon and Isabella of Castile to purge Iberia of all non-Christian elements (for more details, see Iyigun, 2008).

In light of this potential concern, let us make the following observations: First, the main emphasis here is on whether the state and government apparatuses adhered predominantly to and promoted one of the monotheisms - be it via its conquests and trades or through its imperial, colonial and missionary activities. The emphasis is not so much on whether individuals properly and uniformly adhered to their state's monotheism. True, for monotheisms to have imparted the internal and external sociopolitical benefits that we discussed above, a majority of a society's members would have had to have practiced monotheism. But this bring us to the second point which is that this is ultimately an empirical matter. Since we cannot hope to have an accurate measure of individuals' overall intensity of adherence to monotheism and we use a definition which, for the most part, classifies each civilization according to its state and government attitudes regarding monotheism, if the former was what really mattered and not our definition, the empirical work below would refute any effects of monotheism on societies. Finally and related to our second point, we should acknowledge that any such variation and heterogeneity within societies would produce attenuation bias.

Turning back to the particulars of our definition, consider the Carolingian Empire of Charlemagne, the Ottoman Empire, the Bahmani Sultanate and the Mughal Empire. The defining characteristic of the Carolingian Empire was that its King Charlemagne was coronated by the Catholic Pope Leo III in 800 C. E. as the political leader of western Europe crowned by God. During all of his reign, Charlemagne was driven by his desire to conquer lands to his north and east with the intent to spread Christianity and he was quite successful in this endeavour. In contrast, the Ottoman Empire was orders of magnitude more pluralistic in its sociopolitical and imperial policies, at least judged by the norms of its era. Conquered peoples were free to practice their religion as long as they paid the levied taxes. The Greek, Armenian, Jewish and Frankish minorities practiced their trade and commerce and lived in their more or less isolated communities throughout the empire in relative peace. But rising in the bureaucratic or military ranks required a Muslim identity. And the devşirme system, which was introduced by Sultan Murad I in the early 15th century, was the act of gathering and converting to Islam the young boys of the non-Muslim Ottoman populations who were raised in palaces or military barracks with the sole intent of employing them in their adulthood in military or government posts. The Bahmani Sultanate, which ruled in southeast India between 
the early-14th and early-16th centuries, also resembled the Ottoman Empire in that the Muslim groups dominated politically, but the Hindu areas were granted some degree of autonomy and coexistence was facilitated by mutual non-interference. Along these lines, the Muslim Mughal Empire was founded by the Chagatai Turkic ruler Babur and reigned in Northern India between the mid-16th to mid-18th centuries. While it became a politically and religiously intolerant regime later during the leadership of Aurangzeb, to which its seeds of decline is often attributed, by most accounts, the Mughals too were a religiously and politically tolerant society especially during the reign of Akbar. While this is a relatively crude generalization, the societies classified as monotheist in the sample below either resemble the Carolignian Empire or the Ottomans and the Bahmani Sultanate in terms of the role of religion in their political, administrative and social spheres.

To proceed with our investigation, we need a comprehensive dataset on empires, kingdoms and dynasties that cover a wide enough historical timepsan which envelops the birth of the three monotheistic faiths on both ends. With these constraints and demands in mind, I focus on a 4250-year period between 2500 B. C. E. and 1750 C. E. The start date of 2500 B. C. E. is purely due to data limitations as a systematic record of historical civilizations only dates thus far back. And I chose to cap the sample dates at $1750 \mathrm{C}$. E. in order to establish the role of monotheism in socio-politics during the pre-Industrial and prior to the rise of nation states.

There are a variety of alternative sources of data for our purposes and for the historical record of empires, dynasties, and kingdoms, I used Rand McNally \& Co.'s Historical Atlas of the World (2005), Encyclopedia Britannica (http://www.britannica.com), Anglin and Hamblin (1993), Farrington (2002, 2006) and Oxford Atlas of World History (2002). As I provide more detail below, I recorded various facts about these civilizations, the most important of which are their years of foundation and collapse (if they did so before 1750 C. E.). For geographical information on land areas, I relied on the C. I. A.'s The World Factbook. For geographic classification, I divided Europe, the Middle East, Africa, Asia, and America into thirty one regions according to their historical significance and as classified by Anglin and Hamblin. Using these historical records and various sources, I was able to identify 232 civilizations which inhabited one of the five continents. Appendix A presents the 232 limited access orders included in my dataset and Appendix B lists the thirty one historically important regions of the five continents as well as their land areas as compiled from The World Factbook.

Before, we proceed, three data clarifications are in order: First, while Appendix A lists the years in which each civilization was founded and ceased to exist, for all empirical 
tests below the cap $1750 \mathrm{C}$. E. is relevant and, when the date on which a civilization ended is past that date, it also binding. In other words, even if a civilization lasted long past 1750 C. E., I only considered its duration up to that date. I have done this to abstract from the roles of the Industrial Revolution and the rise of the nation states on duration and peak land mass attained. But bear in mind that, since a state was more likely to have been predominantly monotheist later in my time span, capping the duration of societies which existed in the mid-18th century introduces a data construction bias against the main hypothesis advocated in this paper.

Second, this is a data construction exercise from scratch: as such it takes the information available in the main sources of Rand McNally \& Co.'s Historical Atlas of the World (2005), Encyclopedia Britannica, Anglin and Hamblin (1993) and the Atlas of World History (2002) as a starting point. It is intended to be as comprehensive as possible, but to the extent that I could not verify relevant crucial data on the foundation and extinction dates, peak land mass, etc., of the civilizations in question from reliable sources, there are some non-systematic data omissions.

Finally and along the same lines, this is meant to be a data set on all ancient, medieval and pre-Industrial era civilizations that had some autonomy and scale. This is the reason why the data encompass kingdoms, dynasties and empires, as well as early American civilizations about which we have less-specific information on government structure, state organization and social life. This is also the reason why I have excluded from my sample feudal principalities, medieval fiefdoms, suzeranity, the Anatoilan derebeyliks and various city-states. As I shall explain in some detail below, this effectively yielded sovereigns that ruled over at least about $25,000 \mathrm{~km}^{2}$, although the data yielded one outlier state in Asia with only a $4,000 \mathrm{~km}^{2}$ domain (more on which below). Appendix C provides a list of civilizations which have been excluded from the dataset, either because of scale, autonomy or data availability issues.

Table 1.a presents some descriptive statistics. On average, monotheist civilizations lasted significantly less than non-monotheist social orders, with a typical non-monotheist civilization enduring about 370 years and a monotheist society lasting about 285 years. The monotheist societies attained a peak land mass of about 1.75 million $\mathrm{km}^{2}$, which was roughly 50,000 $\mathrm{km}^{2}$ larger than non-monotheist societies. For comparison purposes, when the non-monotheist civilizations of the Americas are excluded, monotheist civilizations lasted only about three decades short of non-monotheist civilizations (284 versus 316 years), whereas their peak land mass was about 200,000 $\mathrm{km}^{2}$ smaller than non-monotheist orders. Hence, the early American civilizations lasted much longer than average (about 640 years) but they occupied more concentrated areas during their reign. Monotheist 
societies were distributed fairly evenly between the Middle East, Africa and Asia, but there were a lot more of them in Europe. In contrast, non-monotheist establishments were predominantly centered in the Middle East, Asia and America.

In the whole sample, the civilization that lasted longest was Kingdom of Elam, a polytheist culture in what is now regions of Iran. It is one of the oldest recorded civilizations that existed between 2200 B. C. E. and 644 B. C. E. It lasted for close to 1600 years. The Muslim Nubian Kingdoms of Northeast Africa, which survived about 1200 years; the Byzantine Empire, which survived 113 decades in Asia Minor, Middle East and the Balkans; and two civilizations of the Americas, Adena in the Mississippi Delta and Olmecs in the Gulf of Mexico, which both lasted 1100 years, were some of the other durable civilizations. It is noteworthy to point out that among these most durable societies only the Nubian Kingdoms and the Byzantine Empire adhered to a monotheism.

In terms of the land mass achieved during the peak of empire, the Arab Umayyad dynasty top the list, with about 14 million $\mathrm{km}^{2}$. That was followed by the Ottomans, various Chinese dynasties, such as Xia, Qin, Han and Song, as well as the Macedonian Empire, with the Ottoman Empire and the Chinese dynasties spreading as large as about 6 million $\mathrm{km}^{2}$ and the Macedonian Empire exceeding 5 million $\mathrm{km}^{2}{ }^{6}$ In contrast, the smallest geographies in my sample were covered by the Sharqi Dynasty (of Jaunpur in northern India, with about 4,000 $\mathrm{km}^{2}$ ), Israel and the Kingdom of Judah (with 26,000 $\mathrm{km}^{2}$ land mass) as well as the various North and Central American ancient civilizations, such as Mochica, Chavin and Chimu, each controlling about 60,000 $\mathrm{km}^{2}$ around the Andes region. Of those outliers in peak land mass, some were monotheist and some were not, but with the exception of the various Chinese dynasties, the societies which attained the largest land masses were all monotheists.

Of the 141 non-monotheist limited access order in my sample, 25 were in the Middle East, 68 in Asia, 15 in Europe, 11 in Africa, and 22 were in the Americas. Some of the notable non-monotheist limited access orders in my data include the Egyptian Kingdoms (Old, Middle and New); the early Anatolian civilizations (Hittites, Luvians, and Lydians); the Mesopotamian Empires (such as Akkadians, Old Babylonian Kingdom, and Assyrian Empire); Iranian Empires (Seleucid, Parthian, and the Persian Empire); var-

\footnotetext{
${ }^{6}$ Here I consider the contiguous land mass of civilizations and exclude, in particular, the colonial conquests of maritime empires of the British, Spanish and the Portuguese.

Furthermore, although the Golden Horde and Mongol raids covered a vast geographic belt with an area of 33 million $\mathrm{km}^{2}$ that stretched from the China Sea to central Europe, I treat this as an outlier in that the era of the Golden Horde and Mongol raids did not typically culminate in stable government and state organizations following the Mongol invasions.
} 
ious Northern and Southern Chinese Dynasties (such as Xiongnu, Xian-bi, Xia, Shang, Song, and Ming); Indian dynasties (Shakas, Guptas, Viyajanagar, etc.); early American civilizations (Aztecs, Incas and Mayans) as well as Alexander the Great's fleeting Macedonian Empire.

Of the 91 monotheist limited access orders, 18 were in the Middle East, 38 in Europe, 17 in Africa and 18 were in Asia. Of those, 46 were Christian, 43 were Muslim and only two were Jewish (Israel/Judah Kingdom, r. 1200 B. C. E. - 584 B. C. E. and Khazaria, r. 650 C. E. to 965 C. E.). Besides Israel and the Judah Kingdom, among the notable monotheist limited access orders were the Axum Empire, the Byzantine Empire, the Holy Roman Empire, the Carolignian Empire, and the Portuguese and British Empires (all Christian); the Arab Empires of the Abbasid, the Ummayad, the Tulunid, the Fatimid, and the Ayyubid dynasties, the Mamluks, the Seljuk Empire, the Ottoman Empire, Sultanate of Delhi, and the Safavids (all Muslim).

The Roman Empire, the Mongol Hordes, Khazaria, Takrur, the Qarakhanids, the Axum Empire, Cumans, Bulgars, Nubian Kingdoms, and the Kievan Rus provide the ten mixed cases where the sovereigns officially adopted a monotheist tradition after the empire or kingdom began: The Roman Empire formally converted to Christianity in 313 C. E. during the reign of Constantine. The Mongol Empire adopted Islam in 1252 when the Mongol Khan Ghazan and his subjects converted to Islam. Given the timing of the exact conversion of these societies to monotheism, I shall classify the Roman Empire as a non-monotheist civilization. This is due to the fact that the Empire lasted only seventeen years after Constantine declared Christianity the official religion of his Empire. In contrast, I will treat the Mongol Empire as a Muslim civilization because Ghazan Khan's adoption of Islam is within 46 years of the foundation of the empire, which by various accounts lasted until the early-16th century. Khazaria was a Turkic civilization that occupied a swath of land in the Caucasus to the northeast of the Black Sea between 650 C. E. and 965 C. E. During the early reign of their state, Khazars practiced Turkic shamanism, but, either around 740 C. E. or 861 C. E., the Khazar ruling classes converted to Judaism. The extent to which the rest of the population adopted Judaism is subject to debate, but some archeological evidence seems to suggest that there were widespread shifts in the burial practices of the wider population consistent with high rates of conversion to Judaism. ${ }^{7}$ In the analysis below, I will assume that Khazaria was a Jewish state. This is more appealing than the alternative (of assuming the Khazar state was non-monotheist) because it lasted slightly less than average (about 32 decades

\footnotetext{
${ }^{7}$ For further details, see Brook (2006) and Golden (1980).
} 
versus the average of 34) and occupied a smaller-than-average geographic region too (about 850,000 $\mathrm{km}^{2}$ as opposed to 1.8 million $\mathrm{km}^{2}$ ). Takrur, an ancient Western African civilization which lasted about half a millennium, converted to Islam around 1030. This is just about halfway through its reign but, given that Takrur lasted longer than average, I shall treat it as a non-monotheist civilization in the baseline estimates. Cumans reigned in Transylvania from 1060 C. E. to 1237, but they converted to Christianity (Roman Catholicism) during prince Barc's tenure only in 1227. As such, I consider them nonmonotheist. Bulgars reigned in the Balkans 679 C. E. and 1018 C. E. and they converted to Orthodox Christianity much later during the reign of Boris I in 869. This is why I categorize them non-monotheist. And while a precise date is harder to pin down for the conversion of the Qarakhanids, the available sources suggest it was rather early on. Thus, I classify them as a Muslim civilization. Nubian Kingdoms (of Nobatia, Pachoras and Alwah) converted to Christianity between 543 C. E. and 575 C. E., due primarily to the work of two missionaries, Julian and his successor Longinus. But they were all founded in the 4th century C. E. and existed for over a millennia in east central Africa until the early 16th century. Thus, I consider them to be Christian. Kievan Rus reigned between 860 C. E. and 1150 C. E. and converted to Orthodox Christianity in 988. Using the same reasoning above regarding the classification of Takrur, Qarakhanids, and the Nubian Kingdoms, I shall classify Kievan Rus as Christian. ${ }^{8}$

Among the civilizations that turned monotheist sometime during their reign, the Axum Empire stands out due to its isolated geography vis-a-vis other monotheistic civilizations as well as its endurance too. It lasted for about seven centuries (270 C. E. to 960 C. E.) in what is modern-day Ethiopia and parts of Yemen. Some folklore has it that the Ark of the Covenant in the Old Testament was actually stored in a monastery of Axum, although there are some alternative theories as to how it ended up in Ethiopia. The first rulers of Axum were pagans and polytheists and the empire grew to be an important trading center of Africa. It converted to Christianity in the fourth century C. E. after a "Christian philosopher by the name of Meropius, bound for India, was shipwrecked on the coast. Although he died, his two companions survived and when they began to spread to word of the gospels, they found a receptive audience," (Farrington, 2006, p. 64). Interestingly, Axum remained the only monotheist culture in Africa for another three centuries when in the 7th century C. E. the Arab Umayyad dynasty began to conquer Northern Africa and convert the local populations to Islam. Since Axum's conversion to Christianity is very early on during its tenure, I classify it as a monotheist

\footnotetext{
${ }^{8}$ For an excellent review of the (ecclesiastical) histories of various ancient and medieval civilizations, see Findlay and O'Rourke (2007, Ch. 1).
} 
social order. As I shall discuss in subsection 3.5, none of these choices of classification influences the main results.

In all that follows, Israel/Judah Kingdom also has a peculiar role in that it represents the only historic civilization that adhered (unlike Khazaria, without a doubt) to Judaism. Nonetheless, it is also one society for which the exact date when it began to subscribe to the unambiguously monotheist version of Judaism is in question (see, for example, Armstrong, 1993, and Stark, 2001). In any case, none of the results I discuss below are influenced by whether Israel/Judah Kingdom is classified as monotheist before or after 606 B. C. E., although as the sole Jewish monotheist order in the sample, it usually ends up being an outlier which robust regression techniques typically omit.

The Sassanian Empire, which ruled in parts of modern day Iran and Mesopotamia between 208 C. E. and 651 C. E., provides another interesting case. Its ruling class, nobility and, for the most part, population subscribed to Zoroastrianism. While not exactly monotheist, Zoroastrianism does have a clear hierarchy among its various divine beings, with Lord Mazda as the Supreme God followed by seven other deities, the Holy Immortals. Nonetheless, precisely due to these distinctions, Zoroastrianism is accepted by some scholars as an early precursor of our modern monotheisms. ${ }^{9}$

In the bottom panel of Table 1.a, I provide a breakdown of civilizations according to their theistic attributes by century. The data confirm the steady rise of monotheistic societies and the displacement of others starting in the fourth century. In particular, there was only one monotheist state (the Christian Axum Empire in sub-Saharan Africa) in the fourth century, which accounts for only 7 percent of the sample for that period. By the eighth century, however, about one fifth of all sovereign countries were monotheist, with one being Jewish (Khazaria) and three being Christian (Axum Empire, Byzantine Empires and the Nubian Kingdom). By the twelfth century more than fifty percent of all countries in the sample was monotheist, while in the seventeenth century it was close to 90 percent.

[Table 1.a about here.]

Before we get to the empirical work, it is worth pointing out some further attributes of the social orders in the dataset. Take for instance the civilizations of the Americas where the indigenous cultures of Mesa Verde, such as the Mogollon Culture and Anasazi, survived in excess of a millennia; Adena lasted 1100 years in the Mississippi Delta;

\footnotetext{
${ }^{9}$ See Armstrong (2006), pp. 9 -14.
} 
Hohokam lived a half a millennium in roughly the same geographic region. Down in South and Central America, the Chavin culture reigned for a millennium in the Andes region and the Classic Maya civilization survived for 650 years in Yucatan. On average, the historical social orders of the Americas controlled limited geographic territories over typically long periods of time. And none of these civilizations were monotheist.

Next examine the kingdoms, dynasties and empires of Asia where you find that only the Xia and Shang Dynasties lasted more than 400 years, but all of the Chinese dynasties controlled vast geographic landscapes in what is now mostly China. The Gupta Empire ruled for a little over two centuries in India and the Srivijaya Empire ruled for six centuries in what is now parts of Indonesia.

Then take note of some interesting civilizations that literally lived, prospered and died by the swords of their founders and rulers. The Macedonian Empire lasted only 40 years but under the rule of Alexander the Great it became a vast and mighty empire that extended from the Balkans to all of Persia, parts of Egypt and the Middle East. The Mongol Empire lasted longer for about three centuries, but during the reign of Genghis Khan it raided territories in the West and East so effectively and brutally that between 1205 C. E. and 1260 C. E. it had managed to stretch between the China Sea and central Europe. Such was the case of the Empire of Tamerlane (the Timurids) which lasted barely over a century but became a powerful regional force in the Near

East by triumphing over the Golden Hordes, sacking Belgrade and temporarily ending the Ottoman Empire's rule in Anatolia and the Balkans at the turn of the 15th century. The Islamic Seljuk Empire lasted only 157 years but moving west from their geographic origins in central Asia, they were able to enter Asia Minor in 1071 C. E. which marked the beginning of the Turkish presence in Anatolia that continues to this day. And the Arab Umayyad Dynasty was able to spread so rapidly between 661 C. E. and 750 C. E. that, by the time it fell in the middle of the 8th century to another Arab dynasty of the Abbasids, the Arab Empires controlled all of the Arabian Peninsula, Middle East, most of southeastern Anatolia, Persia, North Africa and the Iberian Peninsula.

\subsection{Summary Statistics}

I now empirically explore whether the birth of monotheist religions and their adoption by limited access orders had an impact on the duration and the geographic domain of the latter. To this end, I formulate two empirical specifications: the main one, which is a panel of 426 decades and 232 limited access societies and an alternative cross-section series aggregated over the whole time span covering the 232 limited access orders. For each of the 426 decades in my timespan, I created dummy variables for the timespan of 
each limited access order as well as dummy variables for whether a limited access order reigned in each of the thirty three geographic regions. On the basis of this information, I also constructed derivative data on the number of limited access orders that existed, the number of geographic regions under the control of limited access orders during each decade and the average number of regions within the control of each limited access order during every decade.

Table 1.b presents the key summary statistics of the variables used in the empirical analyses. As can be seen in the bottom panel, the average limited access order lasted about 34 decades; there was a positive correlation between the duration length of a limited access order and the birth of the three monotheist religions; the duration of a limited access order was longer among Christian and Jewish establishments whereas this relationship was negative for a Muslim limited access order; the peak land mass of a limited access order was smaller for Christian and Jewish societies, while it was positively linked in the case of Muslim limited access civilizations. As shown in the bottom panel, the average land mass of limited access societies reached a peak of about 1.75 million square-kilometers although this statistic rose over time as well. In the cross-country

sample of 232 total countries, 91 were subscribed to one of the three monotheist religions (i.e. the 86 that were monotheist from the start plus the Mongol Empire, Khazaria, Qarakhanids, Nubian Kingdoms, and the Axum Empire), which corresponds to about 40 percent the whole sample. Table 2 lists and defines all variables used in the empirical analysis.

[Tables 1.b and 2 about here.]

\subsection{Panel-Data Estimates}

My baseline estimates are derived with the panel data using the following specification:

$$
\begin{aligned}
\text { LAO }_{i, t}= & \mu_{t}+\lambda_{1} \text { MONOTHEIST } \\
& +\lambda_{2} \text { MONOTIME }_{i, t} \\
& +\lambda_{3} \text { AOO }_{i, t-1}+\lambda_{3} X_{i, t}+\varepsilon_{i, t},
\end{aligned}
$$

where the left-hand-side variable $L A O_{i, t}$ denotes a dummy variable for the $i$ th limited access order at time $t$ (measured in decades); it takes on the value of one if $i$ exists at time $t$ and zero otherwise. The explanatory variables in this specification include a time trend, $\mu_{t}$, a dummy variable for whether the limited access order was characterized by a 
monotheistic governance and/or social structure, MONOTHEIST ${ }_{i}$, the interaction of the latter with the time trend, MONOTIME $E_{i, t}$, and the lagged-value of the dependent variable, $L A O_{i, t-1}$. Depending on the parsimony of the empirical specification, the control variables in $X_{i, t}$ include variables for which of the main three monotheistic religious faiths had been born at time $t, J U D A I S M_{t}, C H R I S T I A N I T Y_{t}$ or $I S L A M_{t}$, as well as controls for the geographic domain of limited access order $i$.

In Table 3, I present my baseline estimates. They are derived with two populationaverage estimation alternatives: ordinary least squares with robust errors (OLS) and Probit regressions with robust errors. ${ }^{10}$

In columns (1) and (4), I present the estimates from the most parsimonious specification. As shown, the direct effect of monotheism was statistically significant and negative whereas its time-varying impact was positive and significant. According to the column (1) estimates, if a limited access order was associated with one of the three main monotheistic faiths, then the net effect on the likelihood that a kingdom, dynasty or empire existed in any decade was positive starting around the year $140 \mathrm{C}$. E.

The important thing to keep in mind here is that none of the monotheisms were born before 606 B. C. E. Moreover, prior to the 5th century C. E. there were only two historic civilizations that had adhered to monotheism - Israel/the Judah Kingdom and the Roman Empire. While the former embraced the monotheist version of Judaism much later in its history (around 606 B. C. E.), the latter converted to Christianity two decades short of the end of its reign (in 313 C. E.). Thus, in evaluating the impact of monotheism on survival likelihood we need to calculate its impact for dates at which all three monotheisms were born and more widely available to societies.

This was indeed the case according to the OLS estimates in column (1), with the impact of monotheism turning positive around 75 C. E. and the direct and time-varying effects of monotheism yielding a net effect of about 10 percent around the year $1500 \mathrm{C}$. E. That is, around 1500 C. E., a dynasty, empire or kingdom had more than ten percent higher likelihood of survival for an extra century when compared with an average society that was not monotheist around 1500 C. E. ${ }^{11}$ With the Probit estimation, the net impact of monotheism on the likelihood of survival becomes positive around the year $745 \mathrm{C}$. E. And given the estimates in column (4), we again find that the net impact of monotheism

\footnotetext{
${ }^{10}$ In Section 4, I discuss in detail the choice of estimation methods and results derived using various alternatives too.

${ }^{11}$ I calculate these effects by taking into account the positive and significant interaction effect due to MONOTIME. In particular, an existing, non-monotheist civilization had a survival likelihood of slightly less than 87.5 percent for an extra decade in 1500 C. E., whereas an existing monotheist society had one around 98.7 percent. This corresponds to a 11 percent impact on survival an extra century.
} 
on the likelihood of survival another century was roughly 5 percent.

In columns (2) and (5) I add, as additional controls, dummy variables for which of the main three monotheistic religious faiths existed at time $t$, JUDAISM ${ }_{t}, C H R I S T I A N-$ $I T Y_{t}$ and $I S L A M_{t}$. Doing this can help identify if the birth of the three monotheisms had a broad impact on the duration of all civilizations, beyond the direct impact of the monotheism status of each society. As shown in columns (2) and (5), the impact of the birth of Judaism and Christianity on the likelihood of existence of the limited access orders was statistically significant and positive. But note the important distinction between the variable MONOTHEIST and the three religion dummies JUDAISM, CHRISTIANITY, and ISLAM: The former variable is specific to each limited access order while the latter three are variables which attain one after their respective religions are born and zero before. Hence, while the latter can capture a broader and wider-ranging impact of monotheism on all societies, any difference in the estimated coefficients may be suggestive of competition effects between the monotheistic faiths as more of them coexisted later in time (I shall explore this idea further below). The theistic attribute of a society is still important for its longevity: The net impact of MONOTHEIST becomes positive again around $75 \mathrm{C}$. E. in column (2), yielding a net statistically significant and positive impact on the order of about 3 percent on survival likelihood of another century around 1500 C. E. And, in column (5), it has a net statistically significant effect that turns positive around the year $675 \mathrm{C}$. E. with the overall positive effect amounting to again about 11 percent by the year $1500 \mathrm{C}$. E.

In columns (3) and (6), I include geographic dummy variables to control for the central domain of the limited access order $i$. As shown, the variables $E U R O D_{i}$, $M I D E A S T D_{i}, A F R I C A D_{i}$, and $A M E R I C A D_{i}$ all exerted statistically significant and positive effects in column (3), whereas only the dummy for the Middle East coming in negative and significant, with the dummy variable for America entering positively and with a p-value of about 13 percent in column (6). Given the estimated coefficients, we can perhaps infer that, all else equal, civilizations is the Americas lasted longer than their counterparts in other geographies. But more importantly, the inclusion of such controls have no impact on the direct and time-varying roles of monotheism on survival likelihood. The net effect of monotheism turns positive around $5 \mathrm{C}$. E. according to column (3) with a survival rate for an extra century of about 2.5 percent. The Probit estimate results reported in the last column show a net effect which turns positive around the year 670 C. E., with a net impact which amounts to more than 10 percent around the year 1500 C. E. Interestingly, in these expanded specifications, the birth of JUDAISM still has the positive and statistically impact it had in columns (2) and (5). 
Note also that, unlike the specification in column (1), those in (2) through (6) show a significant and negative time trend. In conjunction with the positive and statistically significant time-varying influence of monotheism on the survival of civilizations, we find that empires, kingdoms and dynasties lasted shorter over time. However, adherence to monotheism almost fully countervailed this adverse effect of time on survival - in fact, column (4), (5) and (6) estimates suggest monotheism more than compensated for this negative trend.

[Table 3 about here.]

In sum, these panel data estimates support the idea that monotheistic empires, kingdoms and dynasties did survive longer than others that were not associated with monotheistic religions. The net effect of monotheism on survival an extra century depended on time but, around the year 1500 C. E., it amounted to 10 percent on net consistently in four of the six most specifications. Furthermore, the birth of Judaism in particular seems to have had a positive impact on this survival likelihood and to some de-

gree that of Christianity too, whereas there is some evidence to suggest that the birth of Islam did not. I interpret this latter finding to be suggestive of more intense competition between the three religious traditions as they started to coexist over time.

\subsection{Cross-Section Estimates}

In the cross-section version of the analysis, I estimate

$$
L A O_{i}=\lambda_{0}+\lambda_{1} \text { MONOTHEIST }+\lambda_{2} X_{i}+\varepsilon_{i},
$$

where, depending on the empirical specification, $L A O_{i}$ is either the duration (in decades) of limited access order $i$ or its peak land mass (in square kilometers). The explanatory variable MONOTHEIST $T_{i}$ controls for whether $i$ was monotheist or not.

In the baseline parsimonious estimates reported first, the only control variables in $X_{i}$ include geographic dummy variables for the central domain of the limited access orders, MIDDLEAST, EUROPE, AFRICA, ASIA, and AMERICA. In less parsimonious estimates, I exclude and dissect MONOTHEIST into the three monotheisms of JEWISH, CHRISTIAN, and MUSLIM and include in the analysis the year in which the limited access order was founded, BIRTHYEAR, as well as the interaction of BIRTHYEAR with MONOTHEIST, which I label MONOTIME. In some other specifications, I also control for whether civilization $i$ was founded before or after the 
births of monotheism (i.e., Judaism), Christianity and Islam, denoted respectively by MONOBIRTH, CHRISTBIRTH and ISLAMBIRTH. The motivations for including some of these right-hand-side variables are self explanatory: I include BIRTHYEAR to see if there are observation-specific time effects on the dependent variables and I consider its interaction with MONOTHEIST to check if monotheism had systematically different effects on the left-hand side variables depending on the year in which the empire, kingdom or dynasty was founded.

The main results I report below rely on two alternative estimation techniques: ordinary least squares with robust errors (OLS) and robust regressions. ${ }^{12}$ In Table 4, I present the robust-error OLS estimates where the dependent variable is the land mass (in square kilometers) of limited access order $i$ at its imperial peak. As shown in all of the columns, I do not find that the theistic attribute of the society, MONOTHEIST, had a positive impact on the peak land mass of limited access orders. But, consistent with all of the estimates in Table 3, however, we do find in all columns that the birth of monotheism in the early-7th century B. C. E. provides a common structural break in the peak land mass attained by civilizations historically. Taking the lower estimates provided in the robust regression columns of (5) and (6), we see that societies which were founded after 606 B. C. E. had about $560,000 \mathrm{~km}^{2}$ or roughly 33 percent larger land mass. In all estimates, the continental dummy variable for $A M E R I C A$ is negative and significant reflective of the historically small sovereign establishments on that continent, such as the Mochica, Chavin and Chimu civilizations. This is also true in the case of $E U R O P E$. In contrast, there is somewhat of a positive and significant effect in the case of MIDDLEAST. The American adverse effect on size, even when it is derived from the robust regression estimates, is substantial: whereas on average societies in the dataset attained about 1.7 million $\mathrm{km}^{2}$, all else equal, being America generated a size of about 1.1 million $\mathrm{km}^{2}$ or less, which is about a 35 percent impact.

In columns (2) and (5), I add the control variables for the birth of Christianity and Islam to see of they could provide additional explanatory power. With the robust regression estimate in column (5), we find that the birth of Christianity might have had an adverse statistically significant effect on peak land mass, but not enough to offset the positive and significant impact of the birth of monotheism.

In columns (3) and (6), I dissect MONOTHEIST into the three religions to see if they had differential effects on PEAKLANDMASS. That is, instead of controlling for MONOTHEIST, I include JEWISH, CHRISTIAN, and MUSLIM. As in the

\footnotetext{
${ }^{12}$ Robust regressions first eliminate outlier observations (for which Cook's $D>1$ ) then iteratively selects weights for the remaining observations to reduce the absolute value of the residuals.
} 
earlier estimates in columns (1), (2), (4) and (5), I still control for BIRTHMONO. The interesting result is that, while Jewish and Christian civilizations might have attained smaller geographic land masses on average, their impact is not robust to the adjustment for the role of outliers. But that of Islam seems to have exerted a positive and robust influence on the peak land mass attained, as shown in column (6). Moreover, the robust regression estimate in the final column still implies that the birth of monotheism in 606 B. C. E. had a positive and significant role in leading to larger land mass for all civilizations in general.

[Table 4 about here.]

Next I examined the degree to which the duration of limited access orders over time depended on their theistic characteristics. This also helps us to verify the validity of the results reported in Section 3.3 using an alternative methodology. In Table 5, I present estimates where the dependent variable is the duration of limited access order $i$ (in decades). As shown in columns (1), (2), (4) and (5), we verify that the theistic attribute of a society, MONOTHEIST, did have a positive, statistically significant and meaningful impact on length of reign: for example, around the year $1500 \mathrm{C}$. E., the estimates range from a low of about 12.5 extra decades (an impact of 37 percent on duration) to a high of a little over 22 decades (a 65 percent impact). ${ }^{13}$ In contrast to the results on peak land mass, here we find that the birth of monotheism not to have had a generic impact on the duration of all societies which came to exist after $606 \mathrm{~B}$. C. E. Moreover, we confirm that civilizations in America lasted much longer than others, followed by those in Africa and the Middle East.

[Table 5 about here.]

Before I turn to the robustness of these findings in general, it is important to take note of the fact that, using an alternative cross-section dataset covering 232 kingdoms, dynasties and empires, we find that monotheism exerted a positive and statistically robust influence on the geographic land areas controlled by limited access orders at their historical peaks. To some extent, it is also possible to verify that monotheism

\footnotetext{
${ }^{13}$ The first figure comes from the column (5) estimates. The coefficient on MONOTHEIST is 17.7 and netting out the negative time-varying effect of MONOTIME, which equals $-.0105 * 1,500=15.75$, we get around a 2 decade positive impact. The second figure is derived from column (1) in similar fashion.
} 
influenced duration of limited access orders positively and statistically significantly too, which complements the results identified in section 3.3 (where the emphasis was on the role of theism in the likelihood of survival instead of the average length of duration).

\subsection{Alternative Specifications \& Robustness}

As far as the panel-data estimates shown in Table 3 go, we would ideally like to control for all the fixed effects which might have been in operation at the level of civilizations. Alas, we would run into identification problems if we attempted to introduce fixed effects in conjunction with the controls for the theistic character of historical civilizations. Moreover, even if identification were not a hindrance, the fixed-effect estimates derived from Probit estimates would be biased, because there does not exist a sufficient statistic allowing the fixed effects to be conditioned out of the likelihood. It is with these complications in mind that I originally resorted to population-averaged estimation techniques. Nonetheless, if we focused solely on the general impact of the birth of the three monotheisms on the survival likelihood of historical civilizations by conditioning out the unique theistic attributes of each society along with its other fixed effects, we can examine with a bit more rigor the broad impact of the birth of monotheism on the duration of all civilizations. And, in some sense, this can provide the most stringent empirical test we can pursue given the data limitations, because we shall be able to factor out all fixed effects that applied at the civilization level and the time trends that led to drifts over time.

In the first two columns of Table 6, I report the results derived from fixed-effects panel-data OLS estimates with robust errors. As shown in both columns (1) and (2), we find that the births of Judaism in 606 B. C. E. and Christianity in year 0 as well as that of Islam in 622 C. E., all had positive and statistically significant impacts on the survival likelihood of any given civilization.

Omitted variable biases and reverse causality could be other potential problems which might be plaguing the panel-data estimates shown in Table 3. Recall that the main findings in Section 3.3 relied on a panel that extended well prior to the birth of the three monotheisms. This was done for the dual purpose of relying on a broader dataset and establishing that monotheism influenced duration not just among societies that existed after the monotheisms were born, but also relative to those non-monotheist societies which were around long before monotheism. Hence, by construction, there is bound to be some time varying effects of monotheism on duration (although not necessarily positive and statistically significant). But one could argue that the birth and spread of monotheisms are mainly what account for both the proliferation of civilizations and 
their (most likely) being monotheist. This could be especially relevant to the extent that identification is achieved from across-group variations in the variables of interest (although when lagged dependent variable is included, as we have done throughout Table 3 , the fit of within group estimates were consistently higher).

It is with these concerns in mind that a time trend as well as controls for the birth of monotheism (that is of Judaism around the year 606 B. C. E.), Christianity and Islam were included in Table 3 estimates. Nonetheless, we could address this issue directly by concentrating on a chunk of the data later in time. For example, given the main findings that monotheism began to exert statistically significant positive effects starting somewhere around the early-6th and 8th centuries, it would be worthwhile to examine if we would pick up an unconditional positive impact of monotheism using a truncated dataset which began around $300 \mathrm{C}$. E. (which is when there had been only one monotheist society prior). In columns (3), (4) and (5) of Table 6, I present the results from this alternative specification. Not surprisingly, we do find that monotheism's impact on the likelihood of duration was significantly positive. ${ }^{14}$

[Table 6 about here.]

As far as the main robustness concerns related to the cross-section estimates, we can discard the reverse causality argument more easily than we did with panel data. The reason for this is that, by 9 th century C. E., a vast majority of North Africa, the European continent and the Middle East had become monotheist with the local populations having subscribed to one of the three main monotheisms. Thus, there is a structural time break in the adoption of monotheism in these geographic areas, roughly covering the period between 313 C. E., when the Roman Emperor Constantine I issued the Edict of Milan which legalized Christian worship turning the Roman Empire monotheist, and the 751 C. E. Talas War between the Asian Turks and the Abbasid Muslims, which exposed Turks to Islam and led to their adoption of monotheism as well as its spread in Asia subsequently.

In Table 7, I report results generated with some alternative control variables included in the cross-section empirical specifications. ${ }^{15}$ For example, an interesting modification is provided in columns (1) and (4) where the dummy variables for the religion of the monotheist order, JEWISH, CHRISTIAN, and MUSLIM, are replaced with the

\footnotetext{
${ }^{14}$ Results similar to those reported in columns (3), (4) and (5) are attained for truncated data that begin in the third century C. E. or later.

${ }^{15}$ All of the results reported are from robust regression estimates.
} 
code variable RELIGION, which takes on the value of 1 if the civilization is affiliated with Judaism, 2 if it is related to Christianity, 3 if associated with Islam and 0 otherwise. In columns (2) and (5), I add the interaction of RELIGION with BIRTHYEAR, labeled as RELITIME. As shown in columns (1) and (4), religion exerts a positive and significant impact on peak land mass and a negative and significant impact on duration. In effect, this suggests that peak land mass (duration) grew progressively larger (shorter) as the monotheism in question went from Jewish to Christianity and Islam. The estimates in columns (2) and (5) also suggest this result is robust to the inclusion of a time-interaction effect of religion only with respect to the impact of religion on duration, i.e., in column (5).

In columns (3) and (6), I add MONOTHEIST and drop RELITIME and BIRT HYEAR with the objective of identifying if monotheism or one of its main three traditions mattered more. As shown in columns (3) and (6), the impact of religion on the peak land mass of limited access orders was positive for Islam but it was negative for Christianity, which in turn was still higher than the impact of Judaism. For the duration specification in column (6), this finding is reversed: the impact of religion on the duration of limited access orders was relatively more positive for Judaism than it was for Christianity, but the impact of Islam was negative. These results imply that Muslim civilizations typically conquered more land than Christian societies but they did not last as long.

[Table 7 about here.]

As far as the classification issues are concerned, they are applicable for both the panel-data and cross-section estimates. Recall that, in ten civilizations in the dataset, the rulers (and in some cases, most of the populations) converted to one monotheism after the limited access order was founded (these include the Roman Empire, the Mongols, Khazaria, Takrur, Qarakhanids, the Axum Empire, Cumans, Bulgars, the Nubian Kingdoms, and Kievan Rus). In the case of all of these societies except Khazaria, Takrur, Cumans, Bulgars, and Kievan Rus, the conversions occurred sufficiently late or early so as to enable us to classify Romans as non-monotheist and the others as monotheist. In the case of Khazaria, Takrur and Kievan Rus, there is a great deal more uncertainty about the date and extent of conversions which took place neither early nor late enough to aid with classification. In eight of the ten cases, however, the classification employed was in the direction of attenuation. In any case, I reran all the empirical tests above by 
excluding these ten societies and verified that neither of the findings reported here rides on this classification issue. ${ }^{16}$

A more important coding issue revolves around how to systematically account for the dates of foundation and termination. And this issue is most relevant in the treatment of the various Chinese dynasties, such as the Ming, Song, Shang, or Xia, the various Indian Dynasties which make up the Magadha Empire, such as the Brihadrathas, Pradyotas, Shishunagas, Kanvas, Nandas, Guptas, etc. All of these Indian and Chinese dynasties are traditionally classified as independent and separate observations. These classifications stand in contrast to those of the various Western and Northern European kingdoms, such as the British, Portuguese Empires, the Kingdoms of Sweden, Norway, Denmark, etc., or other Middle Eastern civilizations like the Ottoman and Seljuk Empires, among which no distinction is made in dynastic or ruling class transitions. To assess whether this distinction is important, I combined all the sequential Chinese dynasties to represent three independent limited access orders (the first starting with the Xia in 1994 B. C. E. and running through Shang, Zhou, Qin, to Han in 220 C. E., the second comprising of the era of the Sui and Tang between 581 C. E. and 907 C. E. and the third one beginning with the Song in 960 C. E., running through Liao, Jin, Yuan, Ming, and terminating with the Qing dynasty in 1911 C. E.). I did the same for the Indian dynasties that made up the Magadha Empire (r. 545 B. C. E. to 320 B. C. E.). Then, I reestimated my specifications using the combined Chinese Empires and the Indian Magadha Empire and treating the sequential Arab Muslim empires (of the Rashidun, Umayyads, Abbasids, Tulunids, Fatimids, Ayyubids and the Mamluks) as one too. Neither of these reclassification changes altered the results in any significant way. Thus, I do not report them here.

A similar complication arises from the fact that a number of the civilizations in the data had periods of interregnum; for instance, Kingdom of Portugal between 1580 and 1640 after it was occupied by the Kingdom of Castille; the Ottoman Empire between 1402 and 1413 after Timurids defeated Yildirim (Thunderbolt) Beyazit in the Battle of Ankara, the Byzantine Empire between 1204 and 1261 after Constantinople was sacked by the Fourth Crusaders, and the Kingdom of England between 1649 and 1660 following the English Civil War. I have essentially ignored these periods of interruption in autonomy on the basis of the fact that the Kingdoms and Empires recovered from the loss of sovereignty, typically with in a decade or two. Nonetheless, excluding these observations from the sample does not alter the main results.

\footnotetext{
${ }^{16}$ All results discussed but not shown are available from the author upon request.
} 
Recall that I excluded from the sample a number of smaller city-states and (relatively more autonomous) principalities on the basis of scale. As listed in Appendix $\mathrm{C}$, there are about 35 of those which could be included in the data because we have the primary relevant information on them. These include the Anatolian derebeyliks (of Çaka Bey, Sökmenli, Artuklu, Danişmend, Inaloğlu, Saruhan, Saltuklu, Dulkadir, Germiyan, Karamanoğlu, Ramazanoğlu, Mengücek, Ertena, Aydinoğlu, Karesi, Sahib Ata), the Greek city states (of Arcadia, Phocis, Messania, Argolis, Attica, Laconia, Locris, Epirus, Thessaly, Achaea, Aetolia) and the British Heptarchy Kingdoms of (East Anglia, Essex, Sussex, Wessex, Kent, Mercia, Northumbria). The Anatolian derebeyliks were all Muslim, prospering in various parts of Anatolia for relatively shorter periods of time (typically around a century or less) during the 11th through the 14th centuries. The non-monotheist Greek city-states existed in modern day Greece between 8th century B. C. E. and mid-4th century B. C. E. And the British Heptarchy Kingdoms, which together formed the basis of the Kingdom of England in the early-10th century, existed between the 5th century C. E. and mid-9th century C. E. Most of them began to convert to Christianity in the early-7th century, but given that they survived slightly longer than average, I consider them non-monotheist. The point is that all these city-states, minor kingdoms and derebeyliks controlled small geographic areas, not larger than $30,000 \mathrm{~km}^{2}$, typically around $10,000 \mathrm{~km}^{2}$ (as in the case of Greek city-states) or even below 5,000 $\mathrm{km}^{2}$ (as with Essex, Kent, etc.). In any case, when I included these extra observations in the data (which yielded 267 total cross-section observations), I got results that were very similar to the ones I already reported (in some cases, with stronger statistical significance as well).

Finally, a word on a potential sample selection bias: Given the extremely long time horizon involved here, one could be concerned about antique civilizations that have not been included in the study because of incomplete or lacking data. If such civilizations also lasted long and spread large geographically, the results above could suffer from a bias of sample selection. This is a valid concern although there is a significant positive time trend in the peak land mass of limited access orders. And despite the fact that ancient civilizations typically lasted longer than their younger brethren, this very fact makes its less likely that we lack a large enough chunk of systematic archeological/anthropological evidence on ancient limited access orders that could bias the results above.

\section{Conclusion}

Economists have made significant strides in understanding the links between institutions and economic development. Despite the fact that they also long acknowledge religion as 
an important component of the institutional infrastructure, explicit analyses of the role of religion in sociopolitical and economic development remain scant.

The birth of the three main monotheistic religions is particularly relevant in this regard, because they spread rapidly and eventually came to dominate other religious traditions. Recent work in economic history suggests that the transition from limited access orders to open access orders, in which the political and economic rights of the whole population is well-defined and political rents-seeking has been minimized, has typically been precipitated by prolonged periods of sociopolitical and economic stability (North et al., 2007). Thus, it is imperative to resolve how monotheism and limited access orders came to be strongly intertwined historically and ascertain whether monotheism promoted a modicum of sociopolitical and economic stability in limited access orders.

In this paper, I argue that the birth of monotheism was a major breakthrough in social institutional design and that its various salient features were the main impetus for sociopolitical stability and, to some extent, geographic expansion. Using historical data between 2500 B. C. E. and 1750 C. E. on 225 limited access orders, such as dynasties, kingdoms and empires, I have shown above that the birth of Judaism, Christianity and Islam and the adoption of monotheism by limited access orders had statistically significant effects on the length of reign as well as the average geographical size of all limited access orders. Specifically, kingdoms, dynasties and empires lasted about 340 years on average during this interval. But those historical civilizations that adopted monotheism, regardless of whether it was Judaism, Christianity, or Islam, lasted about 35 to 65 percent longer than non-monotheist social orders and they had about 10 percent higher likelihood to survive an extra century. Beyond the general impact of adherence to monotheism, I cannot find any empirical evidence that Judaism, Christianity or Islam exerted an impact on the length of reign of historical civilizations. I also confirm that monotheism had a roughly similar effect on the geographic domain over which historical civilizations reigned during their peak influence. That is, monotheist limited access orders controlled about twice the land area of their non-monotheist counterparts. Unlike the results on duration, however, I find that adherence to a specific religion - Islam - did exert somewhat of an additional positive impact on the geographic domain of civilizations historically. This is an important results which implies that Muslim civilizations typically conquered more land than Christian societies but they did not last as long.

To wrap things up, let me state that the various ideas I articulated above have some of their precedents in the philosophy, sociology and economics literatures. And they have been rigorously debated and challenged since their inceptions. My main objective was 
to combine a sociopolitical and economic classification of these ideas with a systematic assessment of their empirical validity. 


\section{References}

Acemoglu, D., S. Johnson, and J. Robinson. (2001). "The Colonial Origins of Comparative Development," American Economic Review, 91, 1369-1401.

Anglin, J. P. and W. J. Hamblin (1993). World History to 1648, HarperCollins College Outline, (New York, NY: HarperResource).

Armstrong, K. (1988). Holy War: Crusdes and their Impact on Today's World, (New York, NY: Anchor Books).

Armstrong, K. (1993). A History of God: The 4,000 Year Quest of Judaism, Christianity and Islam, (New York, NY: Ballantine Books).

Armstrong, K. (2006). The Great Transformation: the Beginning of Our Religious Traditions, (New York, NY: Anchor Books).

Barro, R. and R. McCleary. (2003). "Religion and Economic Growth," American Sociological Review, October.

Barro, R. and R. McCleary. (2005). "Which Countries Have State Religions?," Quarterly Journal of Economics, November.

Becker, O. S. and L. Woessmann. (2007). "Was Weber Wrong?: A Human Capital Theory of Protestant Economic History," University of Munich, unpublished manuscript, January.

Botticini, M. and Z. Eckstein. (2005a). "Jewish Occupational Selection: Education, Restrictions, or Minorities?," Journal of Economic History, 65:4, December.

Botticini, M. and Z. Eckstein. (2005b). "From Farmers to Merchants, Voluntary Conversions and Diaspora: A Human Capital Interpretation of Jewish History," University of Minnesota, unpublished manusrcipt.

Brook, K. A. (2006). The Jews of Khazaria. (New York, NY: Rowman \& Littlefield Publishers).

Comte, A. (1974). The Positive Philosophy, (New York: A. M. S. Press), reprint of the 1855 translation of Cours de Philosophie Positive, (New York, C. Blanchard). 
Diaomond, J. (1997). Guns, Germs and Steel: The Fates of Human Societies, (New York, NY: W. W. Norton \& Co.).

Durkheim, E. (1912). The Elementary Forms of the Religious Life, (English translation by Joseph Swain: 1915), (New York, NY: The Free Press).

Encyclopedia Britannica, (2007). www.britannica.com.

Faroqhi, S. (2004). The Ottoman Empire and the World Around It, (London: I. B. Tauris Publishers).

Farrington, K. (2002). Historical Atlas of Empires, (London: Thalamus Publishing).

Farrington, K. (2006). Historical Atlas of Religions, (London: Thalamus Publishing).

Fernandez, R., A. Fogli and C. Olivetti. (2004). "Mothers and Sons: Preference Formation and Female Labor Force Dynamics," Quarterly Journal of Economics, 119 (4), 1249-1299, 2004.

Fernandez, R. (2007). "Culture and Economics," in the New Palgrave Dictionary of Economics, 2nd edition, edited by Steven N. Durlauf and Lawrence E. Blume, Palgrave Macmillan (Basingstoke and New York).

Findlay, R. and K. H. O'Rourke. (2007). Power and Plenty, (Princeton, NJ: Princeton University Press).

Glaeser, E. L., and B. I. Sacerdote. (2002). "Education and Religion." Harvard University, unpublished manuscript.

Glaeser, E. L., R. La Porta, F. Lopez-de-Silanes, and A.Shleifer. (2004). "Do Institutions Cause Growth?" Journal of Economic Growth 9(3): 271-303.

Golden, P. B. (1980). Khazar Studies: An Historio-Philological Inquiry into the Origins of the Khazars. (Budapest: Akademia Kiado).

Greif, A. (2006). Institutions: Theory and History, (Cambridge: Cambridge University Press).

Guiso, L., P. Sapienza, and L. Zingales. (2003). "People's Opium? Religion and Economic Attitudes." Journal of Monetary Economics, 50 (1), 225-82. 
Guiso, L., P. Sapienza, and L. Zingales. (forthcoming). "Does Culture Affect Economic Outcomes?" Journal of Economic Perspectives.

Hill, C. (1967). Reformation to Industrial Revolution: The Making of Modern English Scoiety, Vol. I, 1530-1780, (New York: Random House).

Hillerbrand, H. (1968). The Protestant Reformation, (New York: Harper Collins).

Hirshleifer, J. (1991). "The Paradox of Power," Economics $\&$ Politics, 3:3, November, 177-200.

Hotelling, H. (1929). "Stability in Competition," Economic Journal, 39:1, March, 41-57.

Hume, D. (1911). A Treatise of Human Nature, (London: J. M. Dent and Sons Ltd.).

Iannaccone, L. R. (1992). "Sacrifices and Stigma: Reducing the Free-Riding in Cults, Communes and Other Collectives." Journal of Political Economy 100 (2), April, 271-91.

Iyigun, M. (2006). "Luther and Suleyman," unpublished manuscript, University of Colorado, November.

Iyigun, M. (2008). Tales of Faith in Socioeconomic Progress, book manuscript in preparation, Fall, (Chicago, IL: The University of Chicago Press).

Jaspers, K. (1953). The Origin and Goal of History, Translated from the German by Michael Bullock, (New Haven, CT: Yale University Press).

Jones, E. J. (2003). The European Miracle: Environments, Economies and Geopolitics in the History of Europe and Asia, (Cambridge: Cambridge University Press.).

Kuran, T. (2004a). "The Economic Ascent of the Middle East's Religious Minorities: The Role of Islamic Legal Pluralism," Journal of Legal Studies, 33, June, 2003, 475-515.

Kuran, T. (2004b). "Why the Middle East Is Economically Underdeveloped: Historical Mechanisms of Institutional Stagnation," Journal of Economic Perspectives, 18, Summer, 71-90.

Kuran, T. (2005). "The Logic of Financial Westernization in the Middle East," Journal of Economic Behavior and Organization, 56 (April 2005): 593-615. 
Landes, D. S (1999). The Wealth and Poverty of Nations, (New York, NY: W. W. Norton \& Co.).

Lewis, B. (2002). What Went Wrong? Western Impact and Middle Eastern Response, (London: Phoenix).

MacCulloch, D. (2003). The Reformation: A History, (New York, NY: Viking).

McNeill, W. (1984). The Pursuit of Power : Technology, Armed Force, and Society since A.D. 1000, (Chicago, IL: University of Chicago Press).

Mokyr, J. (1990). The Lever of Riches, (New York: Oxford University Press).

Mokyr, J. (2002). "The Enduring Riddle of the European Miracle: the Enlightenment and the Industrial Revolution," Northwestern University, unpublished manuscipt.

Niebuhr, R. (1932). Moral Man \& Immoral Society: A Study in Ethics and Politics, Library of Theological Ethics, (Kentucky: Westminster John Knox Press).

North, D. C. (1990). Institutions, Institutional Change and Economic Performance (Political Economy of Institutions and Decisions), (Cambridge: Cambridge University Press).

North, D. C., J. J. Wallis and B. R. Weingast. (2006). "A Conceptual Framework for Interpreting Recorded History," NBER Working Paper No: 12795, December.

Oxford (2002). Atlas of World History: Concise Edition, revised 2007 edition (New York, NY: Oxford University Press).

Rand McNally \& Co. (2005). Historical Atlas of the World, revised 2007 edition (Skokie, IL: Rand McNally \& Co.).

Richardson, L. F. (1960). Statistics of Deadly Quarrels, (Pittsburgh, PA: The Boxwood Press).

Rodrik, D., A. Subramanian, and F. Trebbi. (2004). "Institutions Rule: The Primacy of Institutions over Geography and Integration in Economic Development," Journal of Economic Growth, 9. 
Rosenberg, N. and L. E. Birdzell, Jr. (1986). How the West Grew Rich: The Economic Transformation of the Industrial World, (New York, NY: Basic Books).

Spolaore, E. and R. Wacziarg. (2006). "The Diffusion of Development," Stanford University, unpublished manuscript.

Smith, A. (1776) The Wealth of Nations, Complete and Unabridged Edition, (2000 ed., introduction by Robert Reich), (New York, NY: Modern Library Classics).

Stark, R. (2001). One True God: Historical Consequences of Monotheism, (Princeton, NJ: Princeton University Press).

Temin, P. (1997). "Is it Kosher to Talk about Culture?" Journal of Economic History, 57 (2), June, 267-87.

Weber, M. (1930). Protestant Ethic and the Spirit of Capitalism, trans. T. Parsons (New York: Scribner and Sons).

Wilkinson, D. (1980). Deadly Quarrels: Lewis F. Richardson and the Statistical Study of War, (Berkeley, CA: University of California Press).

Woods, F. A. and A. Baltzly. (1915). Is War Diminishing? A Study of the Prevalence of War in Europe from 1450 to the Present Day, (Boston, MA: Houghton Mifflin Co.). 
Table 1.a: Some Descriptive Statistics

Monotheist Dynasties, Kingdoms \& Empires (91 obs.)

\begin{tabular}{|c|c|c|c|c|c|c|c|c|}
\hline Duration & Land & Europe & Africa & M. East & Asia & Jewish & Christian & Muslim \\
\hline \hline 28.4 & $1,748,398$ & 38 & 17 & 18 & 18 & 2 & 46 & 43 \\
\hline As share of total in region: & .72 & .61 & .42 & .21 & $\ldots$ & $\ldots$ & $\ldots$ \\
\hline \multicolumn{2}{|c|}{ Jewish } & 0 & 0 & .02 & .01 & $\ldots$ & $\ldots$ & $\ldots$ \\
\hline \multicolumn{2}{|c|}{ Christian } & .66 & .21 & .02 & .05 & $\ldots$ & $\ldots$ & $\ldots$ \\
\hline \multicolumn{2}{|c|}{ Muslim } & .06 & .40 & .38 & .15 & $\ldots$ & $\ldots$ & $\ldots$ \\
\hline
\end{tabular}

Non-Monotheist Dynasties, Kingdoms \& Empires

All: (141 obs.)

\begin{tabular}{|c|c|c|c|c|c|c|}
\hline Duration & Peak Land & Europe & Africa & M. East & Asia & America \\
\hline \hline 36.6 & $1,701,053$ & 15 & 11 & 25 & 68 & 22 \\
\hline \multicolumn{2}{|l|}{ As share of total in region: } & .28 & .39 & .58 & .79 & 1.0 \\
\hline
\end{tabular}

Excluding the Americas: (119 obs.)

\begin{tabular}{|c|c|}
\hline Duration & Peak Land \\
\hline \hline 31.6 & $1,960,533$ \\
\hline
\end{tabular}

\begin{tabular}{|c|c|c|c|c|c|c|c|c|c|}
\hline \multirow{2}{*}{ Century } & Total & \multicolumn{2}{|c|}{ Monoth. } & \multicolumn{2}{|c|}{ Jewish } & \multicolumn{2}{c|}{ Christian } & \multicolumn{2}{|c|}{ Muslim } \\
\cline { 2 - 12 } & no. & no. & $\%$ & no. & $\%$ & no. & $\%$ & no. & $\%$ \\
\hline \hline 300 - 399 C. E. & 16 & 1 & 7 & 0 & 0 & 1 & 6 & 0 & 0 \\
\hline 500 - 599 C. E. & 16 & 5 & 33 & 0 & 0 & 5 & 33 & 0 & 0 \\
\hline 700 - 799 C. E. & 20 & 4 & 20 & 1 & 5 & 3 & 15 & 0 & 0 \\
\hline 900 - 999 C. E. & 28 & 14 & 50 & 0 & 0 & 11 & 39 & 3 & 11 \\
\hline 1100 - 1199 C. E. & 39 & 21 & 54 & 0 & 0 & 19 & 49 & 2 & 5 \\
\hline 1400 - 1499 C. E. & 26 & 19 & 73 & 0 & 0 & 11 & 42 & 8 & 31 \\
\hline 1600 - 1699 C.E. & 17 & 15 & 89 & 0 & 0 & 12 & 71 & 3 & 18 \\
\hline
\end{tabular}


Table 1.b: Summary Statistics and the Correlation Matrix

\begin{tabular}{|c|c|c|c|c|c|c|c|c|c|c|}
\hline \multicolumn{2}{|c|}{2500 B. C. E. - 1750 C. E. } & \multicolumn{7}{|c|}{ The Correlation Matrix (Panel Data) } \\
\hline$n=98,832$ & Mean & St. Dev. & LAO & MONO & JUDAISM & CHRS. & ISLAM & REL & DEC & MTIME \\
\hline LAO & .084 & .278 & 1 & $\ldots$ & $\ldots$ & $\ldots$ & $\ldots$ & $\ldots$ & $\ldots$ & $\ldots$ \\
\hline MONOTHEIST & .396 & .489 & -.055 & 1 & $\ldots$ & $\ldots$ & $\ldots$ & $\ldots$ & $\ldots$ & $\ldots$ \\
\hline JUDAISM & .695 & .460 & .153 & -.0001 & 1 & $\ldots$ & $\ldots$ & $\ldots$ & $\ldots$ & $\ldots$ \\
\hline CHRISTIANITY & .413 & .492 & .187 & -.0001 & .556 & 1 & $\ldots$ & $\ldots$ & $\ldots$ & $\ldots$ \\
\hline ISLAM & .268 & .443 & .179 & -.0001 & .400 & .720 & 1 & $\ldots$ & $\ldots$ & $\ldots$ \\
\hline RELIGION & .921 & 1.21 & -.064 & .936 & -.0001 & -.0000 & -.0001 & 1 & $\ldots$ & $\ldots$ \\
\hline DECADE & 2125 & 1230 & .197 & -.0001 & .798 & .853 & .766 & -.000 & 1 & $\ldots$ \\
\hline MONOTIME & 842.4 & 1296 & .064 & .802 & .300 & .321 & .288 & .750 & .377 & $\ldots$ \\
\hline
\end{tabular}

\begin{tabular}{|c|c|c|c|c|c|c|c|c|c|c|}
\hline \multicolumn{3}{|c|}{2500 B. C. E. - 1750 C. E. } & \multicolumn{8}{|c|}{ The Correlation Matrix (Cross-Section Data) } \\
\hline$n=232$ & Mean & St. Dev. & $D U R$ & $P L M A S S$ & $M O N O$ & $J W S H$ & $C H R S$ & $M S L M$ & $B Y E A R$ & $M T I M E$ \\
\hline DURATION & 33.4 & 26.9 & 1 & $\ldots$ & $\ldots$ & $\ldots$ & $\ldots$ & $\ldots$ & $\ldots$ & $\ldots$ \\
\hline$P L M A S S$ & $1,719,624$ & $3,290,388$ & -.139 & 1 & $\ldots$ & $\ldots$ & $\ldots$ & $\ldots$ & $\ldots$ & $\ldots$ \\
\hline MONOTHE. & .392 & .489 & -.149 & .007 & 1 & $\ldots$ & $\ldots$ & $\ldots$ & $\ldots$ & $\ldots$ \\
\hline JEWISH & .009 & .092 & .046 & -.036 & .116 & 1 & $\ldots$ & $\ldots$ & $\ldots$ & $\ldots$ \\
\hline CHRISTIAN & .198 & .400 & .100 & -.139 & .619 & -.0416 & 1 & $\ldots$ & $\ldots$ & $\ldots$ \\
\hline$M U S L I M$ & .185 & .389 & -.303 & .048 & .594 & -.045 & -.209 & 1 & $\ldots$ & $\ldots$ \\
\hline BIRTHYEAR & 384.2 & 1003 & -.318 & .045 & .507 & -.063 & .305 & .334 & 1 & $\ldots$ \\
\hline MONOTIME & 400.1 & 558.6 & -.229 & .011 & .894 & -.113 & .538 & .589 & .567 & 1 \\
\hline
\end{tabular}


Table 2.a: Variable Definitions for Panel Data

- $L A O_{i, t}$ : Dummy variable for limited access order $i$ if it exists at $t$.

- MONOTHEIST : Dummy variable for limited access order $i$ if monotheist.

- JUDAISM : Dummy variable; 0 on or before 606 B. C. E. and 1 thereafter.

- CHRISTIANITY : Dummy variable; 0 on or before year 0 and 1 thereafter.

- ISLAM : Dummy variable; 0 on or before 622 C. E. and 1 thereafter.

- $D E C A D E$ : Decade $t$.

- MONOTIME : MONOTHEIST * DECADE.

$E U R O D_{i}$ $M I D E A S T D_{i}:$

- $\left.A S I A D_{i}: \quad\right\}$ Indicator for the geographic region of $L A O i$. $A F R I C A D_{i}$ : $A M E R I C A D_{i}:$,

Table 2.b: Variable Definitions for Cross-Section Data

- $L A O_{i}:\left\{\begin{array}{l}D U R A T I O N_{i}: \text { Number of decades limited access order } i \text { survived. } \\ \text { PEAKLANDMASS }: \text { Land mass achieved at maximum by } L A O_{i}\left(\mathrm{~km}^{2}\right) .\end{array}\right.$

- MONOTHEIST : Dummy variable for a monotheist LAO.

- JEWISH : Dummy variable for a Jewish LAO.

- CHRISTIAN : Dummy variable for a Christian LAO.

- MUSLIM : Dummy variable for a Muslim LAO.

- BIRTHYEAR : Decade in which $L A O$ was founded.

- MONOTIME : MONOTHEIST * BIRTHYEAR

- RELIGION : 1 for Jewish $L A O ; 2$ for Christian $L A O, 3$ for Muslim $L A O ; 0$ otherwise. 
- RELITIME : RELIGION*BIRTHYEAR BIRTHMONO:

- BIRTHCHRST. Dummy variable indicating whether LAO founded before BIRTHISLAM :

or after the birth of the monotheism.

MIDDLEAST:

$N A F R I C A$ :

- EUROPE: $\quad$ Continental dummies for capitals of $L A O$ 's. $A S I A$ :

$A M E R I C A: \quad$ ) 
Table 3: Panel Data Population-Averaged Estimates, 2500 B. C. E. - 1750 C. E.

Dependent Variable: Limited Access Order Dummy, LAO

\begin{tabular}{|c|c|c|c|c|c|c|}
\hline & \multicolumn{3}{|c|}{$\overline{\mathrm{OLS}}$} & \multicolumn{3}{|c|}{ Probit } \\
\hline & $\overline{(11)}$ & 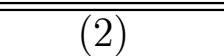 & 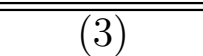 & $\overline{(4)}$ & $\overline{(5)}$ & $\overline{(26)}$ \\
\hline MONOTHEIST & $\begin{array}{c}-.0035^{*} \\
(.0004)\end{array}$ & $\begin{array}{l}-.0035^{*} \\
(.00044)\end{array}$ & $\begin{array}{l}-.0035^{*} \\
(.00051)\end{array}$ & $\begin{array}{c}-.807^{*} \\
(.176)\end{array}$ & $\begin{array}{c}-1.06^{*} \\
(.210)\end{array}$ & $\begin{array}{c}-1.06^{*} \\
(.212)\end{array}$ \\
\hline$D E C A D E_{t}$ & $\begin{array}{c}-.0000003^{* *} \\
(.00000018)\end{array}$ & $\begin{array}{c}-.0000002^{*} \\
(.0000001)\end{array}$ & $\begin{array}{l}-.000002^{*} \\
(.0000006)\end{array}$ & $\begin{array}{c}.00003 \\
(.00002)\end{array}$ & $\begin{array}{c}-.00025^{*} \\
(.00008)\end{array}$ & $\begin{array}{c}-.00025^{*} \\
(.00008)\end{array}$ \\
\hline MONOTIME $E_{i, t}$ & $\begin{array}{l}.0000014^{*} \\
(.0000002)\end{array}$ & $\begin{array}{c}.0000014^{*} \\
(.0000002)\end{array}$ & $\begin{array}{l}.0000014^{*} \\
(.0000002)\end{array}$ & $\begin{array}{c}.00025^{*} \\
(.00006)\end{array}$ & $\begin{array}{c}.00033^{*} \\
(.00007)\end{array}$ & $\begin{array}{c}.00033^{*} \\
(.00007)\end{array}$ \\
\hline$L A O_{i, t-1}$ & $\begin{array}{l}.973^{*} \\
(.002)\end{array}$ & $\begin{array}{c}.973^{*} \\
(.0015)\end{array}$ & $\begin{array}{c}.973^{*} \\
(.0015)\end{array}$ & $\begin{array}{l}4.92^{*} \\
(.051)\end{array}$ & $\begin{array}{c}4.87^{*} \\
(.0 .49)\end{array}$ & $\begin{array}{l}4.86^{*} \\
(.053)\end{array}$ \\
\hline$J U D A I S M_{t}$ & $\ldots$ & $\begin{array}{l}.0034^{*} \\
(.0010)\end{array}$ & $\begin{array}{l}.0034^{*} \\
(.0010)\end{array}$ & $\ldots$ & $\begin{array}{l}.503^{*} \\
(.149)\end{array}$ & $\begin{array}{l}.496^{*} \\
(.147)\end{array}$ \\
\hline CHRISTIANITY $Y_{t}$ & $\ldots$ & $\begin{array}{l}.0035^{*} \\
(.0010)\end{array}$ & $\begin{array}{l}.0035 \\
(.0010)\end{array}$ & $\ldots$ & $\begin{array}{l}.300^{*} \\
(.103)\end{array}$ & $\begin{array}{l}.297^{*} \\
(.103)\end{array}$ \\
\hline$I S L A M_{t}$ & $\ldots$ & $\begin{array}{c}.0015 \\
(.0011)\end{array}$ & $\begin{array}{l}.0015 \\
(.0011)\end{array}$ & $\ldots$ & $\begin{array}{c}.097 \\
(.095)\end{array}$ & $\begin{array}{c}.097 \\
(.095)\end{array}$ \\
\hline$E U R O D_{i}$ & $\ldots$ & $\ldots$ & $\begin{array}{l}.0009^{*} \\
(.0004) \\
\end{array}$ & $\ldots$ & $\ldots$ & $\begin{array}{c}.023 \\
(.035) \\
\end{array}$ \\
\hline$M I D E A S T D_{i}$ & $\ldots$ & $\ldots$ & $\begin{array}{l}.0025^{*} \\
(.0006)\end{array}$ & $\ldots$ & $\ldots$ & $\begin{array}{l}-2.81^{*} \\
(.078)\end{array}$ \\
\hline$\overline{A S I A D_{i}}$ & $\ldots$ & $\ldots$ & $\begin{array}{c}.0005 \\
(.0004)\end{array}$ & $\ldots$ & $\ldots$ & $\begin{array}{l}.0035 \\
(.030)\end{array}$ \\
\hline$A F R I C A D_{i}$ & $\ldots$ & $\ldots$ & $\begin{array}{c}.0010^{*} \\
(.00044)\end{array}$ & $\ldots$ & $\ldots$ & $\begin{array}{c}.012 \\
(.040) \\
\end{array}$ \\
\hline$A M E R I C A D_{i}$ & $\ldots$ & $\ldots$ & $\begin{array}{c}.0022^{*} \\
(.0005)\end{array}$ & $\ldots$ & $\ldots$ & $\begin{array}{l}.049 \\
(.032)\end{array}$ \\
\hline No. of obs. & 98,600 & 98,600 & 98,600 & 98,600 & 98,600 & 98,600 \\
\hline
\end{tabular}

Note: ${ }^{*},{ }^{* *}$ respectively denote significance at the 5 percent and 10 percent levels. 
Table 4: Cross-Section Estimates, 2500 B. C. E. - 1750 C. E.

Dependent Variable: Peak Land Mass

\begin{tabular}{|c|c|c|c|c|c|c|}
\hline & \multicolumn{3}{|c|}{ OLS } & \multicolumn{3}{|c|}{ Robust Regressions } \\
\hline & (1) & $(2)$ & 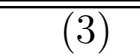 & (4) & $(5)$ & (6) \\
\hline MONOTHEIST & $\begin{array}{c}.160 \\
(.804)\end{array}$ & $\begin{array}{c}.325 \\
(.815)\end{array}$ & $\cdots$ & $\begin{array}{c}.039 \\
(.203)\end{array}$ & $\begin{array}{c}.131 \\
(.217)\end{array}$ & $\cdots$ \\
\hline MIDDLEAST & $\begin{array}{c}.864 \\
(.637)\end{array}$ & $\begin{array}{l}1.54^{*} \\
(.720)\end{array}$ & $\begin{array}{l}1.53^{* *} \\
(.782)\end{array}$ & $\begin{array}{l}.473^{*} \\
(.183)\end{array}$ & $\begin{array}{l}.666^{*} \\
(.244)\end{array}$ & $\begin{array}{l}.501^{*} \\
(.184)\end{array}$ \\
\hline$A F R I C A$ & $\begin{array}{c}-1.74^{*} \\
(.520)\end{array}$ & $\begin{array}{c}-1.77^{*} \\
(.524)\end{array}$ & $\begin{array}{c}-1.68^{*} \\
(.515)\end{array}$ & $\begin{array}{l}-.184 \\
(.160)\end{array}$ & $\begin{array}{l}-.255 \\
(.164)\end{array}$ & $\begin{array}{l}-.242 \\
(.165)\end{array}$ \\
\hline$E U R O P E$ & $\begin{array}{c}-1.77^{*} \\
(.647)\end{array}$ & $\begin{array}{c}-1.81^{*} \\
(.645)\end{array}$ & $\begin{array}{c}-1.48^{*} \\
(.589)\end{array}$ & $\begin{array}{c}-.636^{*} \\
(.142)\end{array}$ & $\begin{array}{c}-.703^{*} \\
(.147) \\
\end{array}$ & $\begin{array}{c}-.518^{*} \\
(.174)\end{array}$ \\
\hline$A S I A$ & $\begin{array}{c}.173 \\
(.835)\end{array}$ & $\begin{array}{l}.129 \\
(.848)\end{array}$ & $\begin{array}{l}-.193 \\
(.582)\end{array}$ & $\begin{array}{c}-.238^{*} \\
(.138)\end{array}$ & $\begin{array}{c}-.303^{*} \\
(.142)\end{array}$ & $\begin{array}{c}-.274^{*} \\
(.143)\end{array}$ \\
\hline$A M E R I C A$ & $\begin{array}{c}-2.07^{*} \\
(.643)\end{array}$ & $\begin{array}{l}-2.10^{*} \\
(.674)\end{array}$ & $\begin{array}{c}-2.58^{*} \\
(.573)\end{array}$ & $\begin{array}{c}-.619^{*} \\
(.186)\end{array}$ & $\begin{array}{c}-.659^{*} \\
(.193)\end{array}$ & $\begin{array}{c}-.645^{*} \\
(.192)\end{array}$ \\
\hline JEWISH & $\ldots$ & $\ldots$ & $\begin{array}{c}-1.81^{*} \\
(.413)\end{array}$ & $\ldots$ & $\ldots$ & $\begin{array}{l}-.220 \\
(.473)\end{array}$ \\
\hline CHRISTIAN & $\ldots$ & $\ldots$ & $\begin{array}{l}-.872 \\
(.560)\end{array}$ & $\ldots$ & $\ldots$ & $\begin{array}{l}-.094 \\
(.156)\end{array}$ \\
\hline$M U S L I M$ & $\ldots$ & $\ldots$ & $\begin{array}{l}-.378 \\
(.713)\end{array}$ & $\ldots$ & $\ldots$ & $\begin{array}{c}.358^{*} \\
(.145)\end{array}$ \\
\hline BIRTHYEAR & $\begin{array}{l}-.0004 \\
(.0004)\end{array}$ & $\begin{array}{l}.00001 \\
(.0005) \\
\end{array}$ & $\begin{array}{l}-.0001 \\
(.0005)\end{array}$ & $\begin{array}{c}-.00014 \\
(.0001)\end{array}$ & $\begin{array}{c}-.00003 \\
(.0001)\end{array}$ & $\begin{array}{l}-.0001 \\
(.0001)\end{array}$ \\
\hline MONOTIME & $\begin{array}{l}.00034 \\
(.0008)\end{array}$ & $\begin{array}{c}.00031 \\
(.00085)\end{array}$ & $\ldots$ & $\begin{array}{c}.00011 \\
(.00018)\end{array}$ & $\begin{array}{l}.00004 \\
(.0002)\end{array}$ & $\ldots$ \\
\hline BIRTHMONO & $\begin{array}{l}1.87^{*} \\
(.783)\end{array}$ & $\begin{array}{l}1.52^{* *} \\
(.816)\end{array}$ & $\begin{array}{l}1.58^{* *} \\
(.880)\end{array}$ & $\begin{array}{c}.514^{*} \\
(.211)\end{array}$ & $\begin{array}{l}610^{*} \\
(.232)\end{array}$ & $\begin{array}{l}.515^{*} \\
(.211)\end{array}$ \\
\hline$C H R I S T B I R T H$ & $\ldots$ & $\begin{array}{l}-.311 \\
(.714)\end{array}$ & $\ldots$ & $\ldots$ & $\begin{array}{c}-.374^{*} \\
(.191)\end{array}$ & $\ldots$ \\
\hline ISLAMBIRTH & $\ldots$ & $\begin{array}{l}-.633 \\
(.530) \\
\end{array}$ & $\ldots$ & $\ldots$ & $\begin{array}{l}.012 \\
(.163)\end{array}$ & $\ldots$ \\
\hline No. of obs. & 232 & 232 & 232 & 232 & 232 & 232 \\
\hline$R^{2}$ & .095 & .099 & .100 & $\ldots$ & $\ldots$ & $\ldots$ \\
\hline
\end{tabular}

Note: ${ }^{*},{ }^{* *}$ respectively denote significance at the 5 percent and 10 percent levels. 
Table 5: Cross-Section Estimates, 2500 B. C. E. - 1750 C. E.

Dependent Variable: Duration

\begin{tabular}{|c|c|c|c|c|c|c|}
\hline & \multicolumn{3}{|c|}{ OLS } & \multicolumn{3}{|c|}{$\overline{\text { Robust Regressions }}$} \\
\hline & $(1)$ & $(2)$ & $(3)$ & $(4)$ & $(5)$ & $(6)$ \\
\hline MONOTHEIST & $\begin{array}{c}21.3^{*} \\
(7.92)\end{array}$ & $\begin{array}{l}18.1^{*} \\
(7.90)\end{array}$ & $\ldots$ & $\begin{array}{l}13.1^{*} \\
(6.71)\end{array}$ & $\begin{array}{l}12.7^{* *} \\
(7.08)\end{array}$ & $\cdots$ \\
\hline MIDDLEAST & $\begin{array}{l}19.8^{*} \\
(6.31)\end{array}$ & $\begin{array}{l}18.6^{*} \\
(7.76)\end{array}$ & $\begin{array}{l}20.8^{*} \\
(6.47)\end{array}$ & $\begin{array}{l}18.8^{*} \\
(6.07)\end{array}$ & $\begin{array}{l}18.8^{*} \\
(7.97)\end{array}$ & $\begin{array}{l}18.8^{*} \\
(5.86)\end{array}$ \\
\hline$A F R I C A$ & $\begin{array}{l}14.8^{*} \\
(5.72)\end{array}$ & $\begin{array}{l}14.4^{*} \\
(5.57)\end{array}$ & $\begin{array}{l}11.9^{*} \\
(5.25)\end{array}$ & $\begin{array}{l}13.0^{*} \\
(5.30)\end{array}$ & $\begin{array}{l}13.0^{*} \\
(5.36)\end{array}$ & $\begin{array}{l}11.2^{*} \\
(5.26)\end{array}$ \\
\hline$E U R O P E$ & $\begin{array}{l}17.8^{*} \\
(5.02)\end{array}$ & $\begin{array}{l}17.0^{*} \\
(4.99)\end{array}$ & $\begin{array}{c}6.49 \\
(6.08)\end{array}$ & $\begin{array}{l}13.7^{*} \\
(4.72)\end{array}$ & $\begin{array}{l}13.2^{*} \\
(4.79)\end{array}$ & $\begin{array}{c}4.36 \\
(5.53)\end{array}$ \\
\hline$A S I A$ & $\begin{array}{l}13.5^{*} \\
(4.40)\end{array}$ & $\begin{array}{l}12.6^{*} \\
(4.33)\end{array}$ & $\begin{array}{l}9.97^{*} \\
(4.46)\end{array}$ & $\begin{array}{l}11.6^{*} \\
(4.56)\end{array}$ & $\begin{array}{l}11.0^{*} \\
(4.64)\end{array}$ & $\begin{array}{l}8.20^{*} \\
(4.54)\end{array}$ \\
\hline$A M E R I C A$ & $\begin{array}{l}47.4^{*} \\
(6.58)\end{array}$ & $\begin{array}{l}45.1^{*} \\
(6.63)\end{array}$ & $\begin{array}{l}43.3^{*} \\
(6.73)\end{array}$ & $\begin{array}{l}46.2^{*} \\
(6.15)\end{array}$ & $\begin{array}{l}44.7^{*} \\
(6.31)\end{array}$ & $\begin{array}{l}41.9^{*} \\
(6.10)\end{array}$ \\
\hline$J E W I S H$ & $\ldots$ & $\ldots$ & $\begin{array}{l}15.5^{* *} \\
(8.08)\end{array}$ & $\ldots$ & $\ldots$ & $\begin{array}{c}18.8 \\
(15.0)\end{array}$ \\
\hline$C H R I S T I A N$ & $\ldots$ & $\ldots$ & $\begin{array}{c}19.4^{*} \\
(5.41)\end{array}$ & $\ldots$ & $\ldots$ & $\begin{array}{l}13.6^{*} \\
(4.95)\end{array}$ \\
\hline$M U S L I M$ & $\ldots$ & $\ldots$ & $\begin{array}{l}-1.63 \\
(3.35)\end{array}$ & $\ldots$ & $\ldots$ & $\begin{array}{l}-3.50 \\
(4.60)\end{array}$ \\
\hline BIRTHYEAR & $\begin{array}{l}-.011^{*} \\
(.0032) \\
\end{array}$ & $\begin{array}{l}-.013^{*} \\
(.0058)\end{array}$ & $\begin{array}{c}-.012^{*} \\
(.003)\end{array}$ & $\begin{array}{c}-.0081^{*} \\
(.0029)\end{array}$ & $\begin{array}{c}-.0083^{*} \\
(.0046) \\
\end{array}$ & $\begin{array}{c}-.0091^{*} \\
(.0027)\end{array}$ \\
\hline MONOTIME & $\begin{array}{l}-.013^{*} \\
(.0065)\end{array}$ & $\begin{array}{l}-.011^{* *} \\
(.0060)\end{array}$ & $\ldots$ & $\begin{array}{l}-.0087 \\
(.0060)\end{array}$ & $\begin{array}{l}-.0079 \\
(.0063)\end{array}$ & $\cdots$ \\
\hline BIRTHMONO & $\begin{array}{l}-.344 \\
(7.57)\end{array}$ & $\begin{array}{l}-2.88 \\
(8.10)\end{array}$ & $\begin{array}{c}3.61 \\
(7.85)\end{array}$ & $\begin{array}{l}-.251 \\
(6.99)\end{array}$ & $\begin{array}{l}-1.80 \\
(7.58)\end{array}$ & $\begin{array}{c}4.62 \\
(6.73)\end{array}$ \\
\hline CHRISTBIRTH & $\ldots$ & $\begin{array}{l}11.4^{* *} \\
(7.10) \\
\end{array}$ & $\ldots$ & $\ldots$ & $\begin{array}{c}6.58 \\
(6.25) \\
\end{array}$ & $\ldots$ \\
\hline ISLAMBIRTH & $\ldots$ & $\begin{array}{l}-6.53 \\
(6.59)\end{array}$ & $\ldots$ & $\ldots$ & $\begin{array}{l}-4.96 \\
(5.34)\end{array}$ & $\ldots$ \\
\hline No. of obs. & 232 & 232 & 232 & 232 & 232 & 232 \\
\hline$R^{2}$ & .299 & .311 & .322 & $\ldots$ & $\ldots$ & $\ldots$ \\
\hline
\end{tabular}

Note: ${ }^{*},{ }^{* *}$ respectively denote significance at the 5 percent and 10 percent levels. 
Table 6: Panel Data Fixed-Effects Estimates, 2500 B. C. E. - 1750 C. E.

Truncated Panel Data Population-Averaged Estimates, 300 C. E. - 1750 C. E.

Dependent Variable: Limited Access Order Dummy, LAO

\begin{tabular}{|c|c|c|c|c|c|}
\hline & \multicolumn{5}{|c|}{ OLS } \\
\hline & (1) & $(2)$ & $(3)$ & $(4)$ & $(5)$ \\
\hline MONOTHEIST & $\cdots$ & $\cdots$ & $\begin{array}{l}.0034^{*} \\
(.0011)\end{array}$ & $\begin{array}{l}.0032^{*} \\
(.0006)\end{array}$ & $\begin{array}{l}.0033^{*} \\
(.0006)\end{array}$ \\
\hline$\overline{D E C A D E_{t}}$ & $\begin{array}{l}-.0000014 \\
(.0000023)\end{array}$ & $\begin{array}{c}-.0000019^{* *} \\
(.0000006)\end{array}$ & $\begin{array}{c}-.0000038^{*} \\
(.0000012)\end{array}$ & $\begin{array}{c}-.0000039^{*} \\
(.0000010)\end{array}$ & $\begin{array}{l}-.000007^{*} \\
(.0000016)\end{array}$ \\
\hline$J U D A I S M_{t}$ & $\begin{array}{c}.043^{*} \\
(.0033)\end{array}$ & $\begin{array}{l}.0039^{*} \\
(.0008)\end{array}$ & $\ldots$ & $\cdots$ & $\ldots$ \\
\hline$C H R I S T I A N_{\cdot t}$ & $\begin{array}{c}.046^{*} \\
(.0035)\end{array}$ & $\begin{array}{l}.0036^{*} \\
(.0009)\end{array}$ & $\ldots$ & $\cdots$ & $\ldots$ \\
\hline$I S L A M_{t}$ & $\begin{array}{l}.058^{*} \\
(.004)\end{array}$ & $\begin{array}{l}.0019^{* *} \\
(.0010)\end{array}$ & $\ldots$ & $\ldots$ & $\begin{array}{l}.0050^{*} \\
(.0017)\end{array}$ \\
\hline$L A O_{i, t-1}$ & $\ldots$ & $\begin{array}{c}.968^{*} \\
(.0021)\end{array}$ & $\begin{array}{c}.965^{*} \\
(.0014)\end{array}$ & $\begin{array}{c}.973^{*} \\
(.0018)\end{array}$ & $\begin{array}{c}.973^{*} \\
(.0019)\end{array}$ \\
\hline$E U R O D_{i}$ & $\ldots$ & $\ldots$ & $\ldots$ & $\begin{array}{c}.0032^{*} \\
(.00076)\end{array}$ & $\begin{array}{c}.0032 \\
(.00078)\end{array}$ \\
\hline$\overline{M I D E A S T D_{i}}$ & $\ldots$ & $\ldots$ & $\ldots$ & $\begin{array}{c}.014^{*} \\
(.0036)\end{array}$ & $\begin{array}{c}.022^{*} \\
(.0047)\end{array}$ \\
\hline$\overline{A S I A D_{i}}$ & $\ldots$ & $\ldots$ & $\ldots$ & $\begin{array}{l}.0030^{*} \\
(.0005)\end{array}$ & $\begin{array}{c}.0031^{*} \\
(.00052)\end{array}$ \\
\hline$A F R I C A D_{i}$ & $\cdots$ & $\ldots$ & $\ldots$ & $\begin{array}{l}.0031^{*} \\
(.0012)\end{array}$ & $\begin{array}{l}.0032^{*} \\
(.0011)\end{array}$ \\
\hline$A M E R I C A D_{i}$ & $\ldots$ & $\cdots$ & $\ldots$ & $\begin{array}{l}.0045^{*} \\
(.0014)\end{array}$ & $\begin{array}{l}.0046^{*} \\
(.0014)\end{array}$ \\
\hline No. of obs. & 98,832 & 98,600 & 32,915 & 32,915 & 32,915 \\
\hline$R^{2}$ & .040 & .941 & $\ldots$ & $\ldots$ & $\ldots$ \\
\hline
\end{tabular}

Note: ${ }^{*},{ }^{* *}$ respectively denote significance at the 5 percent and 10 percent levels. 
Table 7: Cross-Section Robust Regression Estimates, 2500 B. C. E. - 1750 C. E.

Dependent Variable: (1) - (3) Peak Land Mass; (4) - (6) Duration

\begin{tabular}{|c|c|c|c|c|c|c|}
\hline & & & & & & \\
\hline & $(1)$ & $(2)$ & $(3)$ & $(4)$ & $(5)$ & $(6)$ \\
\hline MONOTHEIST & $\cdots$ & $\cdots$ & $\begin{array}{c}-.683^{* *} \\
(.377)\end{array}$ & $\cdots$ & $\cdots$ & $\begin{array}{l}42.2^{*} \\
(12.7)\end{array}$ \\
\hline$M I D D L E A S T$ & $\begin{array}{c}.668^{*} \\
(.102)\end{array}$ & $\begin{array}{l}.650^{*} \\
(.113)\end{array}$ & $\begin{array}{l}.721^{*} \\
(.106)\end{array}$ & $\begin{array}{c}26.4^{*} \\
(3.59)\end{array}$ & $\begin{array}{l}20.5^{*} \\
(3.91)\end{array}$ & $\begin{array}{l}26.9^{*} \\
(3.56)\end{array}$ \\
\hline$A F R I C A$ & $\begin{array}{l}-.055 \\
(.149) \\
\end{array}$ & $\begin{array}{l}-.050 \\
(.152) \\
\end{array}$ & $\begin{array}{l}-.142 \\
(.155) \\
\end{array}$ & $\begin{array}{l}8.85^{* *} \\
(5.25) \\
\end{array}$ & $\begin{array}{l}12.5^{*} \\
(5.28) \\
\end{array}$ & $\begin{array}{l}9.32^{*} \\
(5.20) \\
\end{array}$ \\
\hline$E U R O P E$ & $\begin{array}{c}-.457^{*} \\
(.126)\end{array}$ & $\begin{array}{c}-.448^{*} \\
(.136)\end{array}$ & $\begin{array}{c}-.413^{*} \\
(.149)\end{array}$ & $\begin{array}{c}5.93 \\
(4.42)\end{array}$ & $\begin{array}{l}13.0^{*} \\
(4.71)\end{array}$ & $\begin{array}{l}-1.34 \\
(4.99)\end{array}$ \\
\hline$A S I A$ & $\begin{array}{l}-.079 \\
(.116)\end{array}$ & $\begin{array}{l}-.054 \\
(.132)\end{array}$ & $\begin{array}{l}-.113 \\
(.121)\end{array}$ & $\begin{array}{c}1.41 \\
(4.08)\end{array}$ & $\begin{array}{l}10.1^{*} \\
(4.56)\end{array}$ & $\begin{array}{c}.490 \\
(4.05)\end{array}$ \\
\hline$A M E R I C A$ & $\begin{array}{c}-.426^{*} \\
(.166) \\
\end{array}$ & $\begin{array}{c}-.404^{*} \\
(.178) \\
\end{array}$ & $\begin{array}{c}-.470^{*} \\
(.172) \\
\end{array}$ & $\begin{array}{c}36.3^{*} \\
(5.81) \\
\end{array}$ & $\begin{array}{l}44.2^{*} \\
(6.15) \\
\end{array}$ & $\begin{array}{l}35.9^{*} \\
(5.77) \\
\end{array}$ \\
\hline RELIGION & $\begin{array}{l}.069^{* *} \\
(.035)\end{array}$ & $\begin{array}{c}.140 \\
(.096) \\
\end{array}$ & $\begin{array}{l}.338^{*} \\
(.142) \\
\end{array}$ & $\begin{array}{c}-3.21^{*} \\
(1.24)\end{array}$ & $\begin{array}{c}2.67 \\
(3.32) \\
\end{array}$ & $\begin{array}{l}-18.2^{*} \\
(4.75)\end{array}$ \\
\hline RELITIME & $\ldots$ & $\begin{array}{l}-.00006 \\
(.00008)\end{array}$ & $\ldots$ & $\ldots$ & $\begin{array}{l}-.0022 \\
(.0028)\end{array}$ & $\ldots$ \\
\hline BIRTHYEAR & $\ldots$ & $\begin{array}{l}-.00001 \\
(.00006) \\
\end{array}$ & $\ldots$ & $\ldots$ & $\begin{array}{c}-.0076^{*} \\
(.0019) \\
\end{array}$ & $\ldots$ \\
\hline No. of obs. & 232 & 232 & 232 & 232 & 232 & 232 \\
\hline
\end{tabular}

Note: ${ }^{*},{ }^{* *}$ respectively denote significance at the 5 percent and 10 percent levels. 
Appendix A: Dynasties, Kingdoms \& Empires - 2500 B. C. E. to 1750 C. E.

(j : Jewish; c: Christian; m: Muslim)

(Peak Land Mass, PLM, in millions of $\mathrm{km}^{2}$ )

\begin{tabular}{|c|c|c|c|c|c|}
\hline \multicolumn{6}{|c|}{ MIDDLE EAST: } \\
\hline & Name & Birth Year & Death Year & PLM & Region \\
\hline 1 & Early Dynasty & 2900 B.C.E. & 2371 B.C.E. & 1 & Mesopotamia \\
\hline 2 & Ebla & 2400 B.C.E. & 2250 B.C.E. & 0.09 & Syria \\
\hline 3 & Akkadian Empire & 2371 B.C.E. & 2230 B.C.E. & .65 & Mesopotamia \\
\hline 4 & Gutains & 2230 B.C.E. & 2112 B.C.E. & .43 & $"$ \\
\hline 5 & Kingdom of Elam & 2200 B.C.E. & 644 B.C.E. & .50 & Iran \\
\hline 6 & Ur Dynasty & 2112 B.C.E. & 2004 B.C.E. & .43 & Mesopotamia \\
\hline 7 & Isin, Larsa \& Mari & 2002 B.C.E. & 1792 B.C.E. & .43 & $"$ \\
\hline 8 & Old Babylonian & 1792 B.C.E. & 1595 B.C.E. & .50 & $"$ \\
\hline 9 & Mittani-Kassite & 1595 B.C.E. & 1200 B.C.E. & .43 & Mesopotamia \\
\hline 10 & Hittites & 1450 B.C.E. & 1200 B.C.E. & .75 & Anatolia \\
\hline 11 & Aramean Kingdom & 1350 B.C.E. & 850 B.C.E. & 185 & Syria \\
\hline 12 & Assyrians & 1305 B.C.E. & 609 B.C.E. & 1.4 & Mesopotamia \\
\hline 13 & Israel $^{j}$ & 1200 B.C.E. & 584 B.C.E. & .026 & Isael/Palestine \\
\hline 14 & Luvians & 1200 B.C.E. & 680 B.C.E. & .75 & Anatolia \\
\hline 15 & Phrygians & 1000 B. C. E. & 690 B. C. E. & 20 & $"$ \\
\hline 16 & Urartu & 880 B.C.E. & 590 B.C.E. & .15 & Armenia \\
\hline 17 & Lydia & 680 B.C.E. & 547 B.C.E. & .08 & Anatolia \\
\hline 18 & Media & 728 B.C.E. & 559 B.C.E. & 1.64 & Iran \\
\hline 19 & Babylonia & 626 B.C.E. & 539 B.C.E. & .50 & Mesopotamia \\
\hline 20 & Achaemenid Empire & 559 B.C.E. & 330 B.C.E. & 4 & $\begin{array}{c}\text { Iran, } \\
\text { Anatolia, } \\
\text { Mesopotamia, } \\
\text { Egypt, } \\
\text { Armenia, } \\
\text { Isreal/Palestine } \\
\text { Syria. }\end{array}$ \\
\hline 21 & Empire of Antigonus & 323 B. C. E. & 301 B. C. E. & .50 & $\begin{array}{c}\text { Israel/Palestine } \\
\text { Syria } \\
\text { Anatolia }\end{array}$ \\
\hline 22 & K. of Atropatene & 323 B.C.E. & 20 B.C.E. & .25 & Armenia \\
\hline 23 & Seleucid Empire & 305 B.C.E. & 64 B.C.E. & 3.9 & $\begin{array}{l}\text { Mesopotamia, } \\
\text { Iran. }\end{array}$ \\
\hline 24 & Parthian Empire & 250 B.C.E. & 226 C. E. & 2.5 & $\begin{array}{l}\text { Mesopotamia, } \\
\text { Iran. }\end{array}$ \\
\hline
\end{tabular}




\section{Appendix A (continued):}

\begin{tabular}{|c|c|c|c|c|c|}
\hline \multicolumn{6}{|c|}{ MIDDLE EAST (continued) } \\
\hline & Name & Birth Year & Death Year & PLM & Region \\
\hline 25 & Sasanian Empire & 208 C. E. & 651 C. E. & 7.9 & $\begin{array}{l}\text { Mesopotamia, } \\
\text { Iran. }\end{array}$ \\
\hline 26 & Rashidun $^{\mathrm{m}}$ & 632 C. E. & 661 C. E. & 9 & $\begin{array}{c}\text { Arab pen., } \\
\text { Mesopotamia, } \\
\text { N. Africa }\end{array}$ \\
\hline 27 & Umayyads $^{\mathrm{m}}$ & 661 C. E. & 750 C. E. & 13.2 & $\begin{array}{c}\text { Arab pen., } \\
\text { Mesopotamia, } \\
\text { N. Africa } \\
\text { Iberian Pen. }\end{array}$ \\
\hline 28 & Abbasids $^{\mathrm{m}}$ & 750 C. E. & 861 C.E. & 11 & $\begin{array}{l}\text { Arab pen., } \\
\text { Mesopotamia, } \\
\text { N. Africa } \\
\text { Iberian Pen. }\end{array}$ \\
\hline 29 & Qarmatians $^{\mathrm{m}}$ & 819 C. E. & 1005 C. E. & 1.7 & $\begin{array}{l}\text { Arabian pen., } \\
\text { Mesopotamia. }\end{array}$ \\
\hline 30 & Tulunids ${ }^{m}$ & 868 C. E. & 905 C. E. & 3 & $\begin{array}{l}\text { Arabian pen., } \\
\text { Mesopotamia, } \\
\text { Egypt, } \\
\text { N. Africa. }\end{array}$ \\
\hline 31 & Hamdanids $^{\mathrm{m}}$ & 905 C. E. & 1004 C. E. & .20 & $\begin{array}{c}\text { Mesopotamia, } \\
\text { Syria, } \\
\text { Iraq. }\end{array}$ \\
\hline 32 & Fatimids $^{\mathrm{m}}$ & 909 C. E. & 1171 C. E. & 5 & $\begin{array}{l}\text { Arabian pen., } \\
\text { Mesopotamia, } \\
\text { Egypt, } \\
\text { N. Africa. }\end{array}$ \\
\hline 33 & Buyids $^{\mathrm{m}}$ & 945 C. E. & 1055 C. E. & 1.5 & $\begin{array}{c}\text { Iran, } \\
\text { C. Asia } \\
\text { Anatolia. }\end{array}$ \\
\hline 34 & Ghaznavids $^{\mathrm{m}}$ & 977 C. E. & 1186 C. E. & 2.2 & $\begin{array}{c}\text { Iran, } \\
\text { C. Asia. }\end{array}$ \\
\hline 35 & Seljuk Empire $^{\mathrm{m}}$ & 1037 C. E. & 1194 C. E. & 3.9 & $\begin{array}{c}\text { Anatolia, } \\
\text { Mesopotamia, } \\
\text { Turkestan. }\end{array}$ \\
\hline 36 & K. of Jerusalem ${ }^{c}$ & 1099 C. E. & 1291 C. E. & .026 & Israel/Palestine \\
\hline
\end{tabular}




\section{Appendix A (continued):}

\begin{tabular}{|c|c|c|c|c|c|}
\hline \multicolumn{6}{|c|}{ MIDDLE EAST (continued) } \\
\hline & Name & Birth Year & Death Year & PLM & Region \\
\hline 37 & Ayyubids $^{\mathrm{m}}$ & 1172 C. E. & 1250 C. E. & 3 & $\begin{array}{c}\text { Arabian pen., } \\
\text { Mesopotamia, } \\
\text { Egypt, } \\
\text { N. Africa. }\end{array}$ \\
\hline 38 & Mamluks ${ }^{m}$ & 1250 C. E. & 1517 C. E. & 1.5 & $\begin{array}{c}\text { Arabian pen., } \\
\text { Mesopotamia, } \\
\text { Egypt, } \\
\text { N. Africa. }\end{array}$ \\
\hline 39 & Ilkhanate Khanate & 1260 C. E. & 1324 C. E. & 2.2 & Iran \\
\hline 40 & Ottoman Empire ${ }^{\mathrm{m}}$ & 1299 C. E. & 1923 C. E. & 5.5 & $\begin{array}{c}\text { Anatolia, } \\
\text { Mesopotamia, } \\
\text { Balkans, } \\
\text { E. Europe, } \\
\text { N. Africa } \\
\text { Arabian Pen. }\end{array}$ \\
\hline 41 & Ak Koyunlum & 1378 C. E. & 1508 C. E. & .60 & $\begin{array}{c}\text { Anatolia } \\
\text { Iran. }\end{array}$ \\
\hline 42 & Kara Koyunlum & 1390 C. E. & 1468 C. E. & .50 & $\begin{array}{c}\text { Anatolia } \\
\text { Mesopotamia, } \\
\text { Iran, } \\
\text { Iraq. }\end{array}$ \\
\hline 43 & Safavid Empire ${ }^{\mathrm{m}}$ & 1492 C. E. & 1736 C. E. & 2.9 & $\begin{array}{c}\text { Iran } \\
\text { Arabian pen., } \\
\text { Mesopotamia, } \\
\text { Egypt, } \\
\text { N. Africa. }\end{array}$ \\
\hline
\end{tabular}




\section{Appendix A (continued):}

\begin{tabular}{|c|c|c|c|c|c|}
\hline \multicolumn{6}{|c|}{ EUROPE: } \\
\hline & Name & Birth Year & Death Year & PLM & Region \\
\hline 1 & Minoan Civilization & 2000 B. C. E. & 1450 B. C. E. & .07 & Balkan pen. \\
\hline 2 & Etruscans & 1200 B. C. E. & 100 B. C. E. & .07 & Italian pen. \\
\hline 3 & Athenian Empire & 479 B. C. E. & 404 C. E. & .12 & Balkans \\
\hline 4 & Macedonian Empire & 360 B. C. E. & 320 B. C. E. & 5.4 & $\begin{array}{c}\text { Balkans, } \\
\text { Anatolia, } \\
\text { C. Asia, } \\
\text { Iran, } \\
\text { NW. India. }\end{array}$ \\
\hline 5 & Dacia Kingdom & 350 B. C. E. & 40 B. C. E. & .70 & E. Europe \\
\hline 6 & Roman Empire & 200 B.C.E. & 330 C. E. & 5.7 & $\begin{array}{l}\text { Italian pen., } \\
\text { Mesopotamia, } \\
\text { Anatolia, } \\
\text { N. Africa }\end{array}$ \\
\hline 7 & Sarmatians & 200 B. C. E. & 200 C. E. & 1 & $\begin{array}{c}\text { Balkans, } \\
\text { S. Russia. }\end{array}$ \\
\hline 8 & Byzantine Empire $^{c}$ & 330 C. E. & 1453 C. E. & 4.5 & $\begin{array}{c}\text { Anatolia, } \\
\text { Balkans, } \\
\text { E. Europe, } \\
\text { Mesopotamia, } \\
\text { N. Africa. }\end{array}$ \\
\hline 9 & Visigoths $^{c}$ & 382 C. E. & 711 C. E. & .50 & N. C. Europe \\
\hline 10 & Merovingian Kingdom ${ }^{c}$ & 476 C. E. & 750 C. E. & .45 & W. Europe \\
\hline 11 & K. of Italy (Odoacer) $)^{c}$ & 476 C. E. & 493 C. E. & .30 & S. C. Europe \\
\hline 12 & K. of Italy (Ostrogothic) ${ }^{\mathrm{c}}$ & 493 C. E. & 100 B. C. E. & .45 & Italian pen. \\
\hline 13 & Thuringian Kingdom & 500 C. E. & 730 C. E. & .02 & C. Europe \\
\hline 14 & Avars & 562 C.E. & 805 C.E. & .10 & Balkans \\
\hline 15 & K. of Italy (Lombard) ${ }^{c}$ & 568 C. E. & 774 C. E. & .30 & Italian pen. \\
\hline 16 & Bulgars (1 ${ }^{\text {st }}$ Empire) & 679 C.E. & 1018 C.E. & .11 & Balkans \\
\hline 17 & Kingdom of Denmark ${ }^{c}$ & 737 C. E. & 1397 C. E. & .04 & N. C. Europe \\
\hline 18 & Carolignian Empire & 750 C. E. & 887 C. E. & 1.2 & $\begin{array}{l}\text { W. Europe } \\
\text { C. Europe }\end{array}$ \\
\hline 19 & Caliphate of Cordoba $^{\mathrm{m}}$ & 755 C. E. & 1009 C. E. & .46 & Iberian pen. \\
\hline 20 & K. of Pamplona (Navarre) & 824 C. E. & 1513 C. E. & .70 & Iberian pen. \\
\hline 21 & Kingdom of Alba ${ }^{c}$ & 843 C. E. & 1286 C. E. & .06 & N. W. Europe \\
\hline 22 & Kingdom of Scotland & 843 C.E. & 1707 C.E. & .08 & N. W. Europe \\
\hline 23 & Magyars & 850 C.E. & 955 C.E. & .10 & Balkans \\
\hline
\end{tabular}




\section{Appendix A (continued):}

\begin{tabular}{|c|c|c|c|c|c|}
\hline \multicolumn{6}{|c|}{ EUROPE: } \\
\hline & Name & Birth Year & Death Year & PLM & Region \\
\hline 24 & Kingdom of Castille & 850 C. E. & 1479 C. E. & .15 & Iberian pen. \\
\hline 25 & Moravians & 850 C. E. & 900 C. E. & .05 & E. Europe \\
\hline 26 & Kingdom of Norwayc $^{c}$ & 872 C. E. & 1397 C. E. & .39 & N. Europe \\
\hline 27 & Pechenegs & 900 & 107 & 1.5 & $\begin{array}{c}\text { Balkans } \\
\text { S. Russia }\end{array}$ \\
\hline 28 & Kingdom of Leon ${ }^{c}$ & 910 C. E. & 1230 C. E. & .10 & Iberian pen. \\
\hline 29 & Kingdom of England & 927 C. E. & 1649 C. E. & .17 & N. W. Europe \\
\hline 30 & Kingdom of Arles ${ }^{c}$ & 933 C. E. & 1032 C. E. & .13 & S. W. Europe \\
\hline 31 & Holy Roman Empire & 962 C. E. & 1806 C. E. & 1.8 & C. Europe \\
\hline 32 & Caretian Dynasty & 987 C. E. & 1328 C. E. & .55 & S. W. Europe \\
\hline 33 & Valenciam $^{m}$ & 1010 C. E. & 1238 C. E. & .02 & Iberian pen. \\
\hline 34 & K. of Poland (Piast) & 1025 C. E. & 1385 C. E. & .30 & C. Europe \\
\hline 35 & Kingdom of Naples & 1130 C. E. & 1860 C. E. & .10 & Italian pen. \\
\hline 36 & Kingdom of Aragon ${ }^{c}$ & 1035 C. E. & 1707 C. E. & .10 & W. Europe \\
\hline 37 & Cumans & 1060 C.E. & 1237 C.E. & 1 & Transylvania \\
\hline 38 & Kingdom of Sicily ${ }^{c}$ & 1130 C.E. & 1282 C.E. & .07 & Mediterranean \\
\hline 39 & Kingdom of Portugal $^{c}$ & 1139 C. E. & 1910 C. E. & .09 & Western Europe \\
\hline 40 & Angevin Dynasty ${ }^{c}$ & 1154 C. E. & 1399 C. E. & .82 & W. Europe \\
\hline 41 & Bulgarian Empire $^{\mathrm{c}}\left(2^{\text {nd }}\right)$ & 1185 C. E. & 1396 C. E. & .11 & Balkans \\
\hline 42 & K. of Granada (Nasrid) ${ }^{\mathrm{m}}$ & 1238 C.E. & 1492 C.E. & .07 & Iberian pen. \\
\hline 43 & K. of Lithuania & 1251 C. E. & 1263 C. E. & .07 & N. E. Europe \\
\hline 44 & Kingdom of Cyprus ${ }^{\mathrm{c}}$ & 1291 C.E. & 1480 C.E. & .09 & Mediterranean \\
\hline 45 & K. of Poland (Jagiellon) ${ }^{c}$ & 1385 C.E. & 1569 C. E. & .30 & C. Europe \\
\hline 46 & Kalmar Union ${ }^{\mathrm{c}}$ & 1397 C. E. & 1524 C. E. & .76 & Scandinavia \\
\hline 47 & Khanate of Crimea $^{\mathrm{c}}$ & 1443 C. E. & 1783 C. E. & .03 & N. E. Europe \\
\hline 48 & Muscovy (Russian Emp.) & 1462 C. E. & 1795 C. E. & 16.5 & N. E. Europe \\
\hline 49 & Cmw. of Poland-Lithuaniac & 1569 C. E. & 1791 C. E. & .37 & N. E. Europe \\
\hline 50 & Duchy of Savoy ${ }^{\mathrm{c}}$ & 1559 C. E. & 1601 C. E. & .05 & W. Europe \\
\hline 51 & Dutch Kingdom (United. Prov.) & 1581 C. E. & 1795 C. E. & .03 & N. W. Europe \\
\hline 52 & Empire of Sweden ${ }^{c}$ & 1611 C. E. & 1718 C. E. & .60 & Scandinavia \\
\hline 53 & Kingdom of Prussia ${ }^{c}$ & 1708 C. E. & 1918 C. E. & .35 & N. E. Europe \\
\hline
\end{tabular}




\section{Appendix A (continued):}

\begin{tabular}{|c|c|c|c|c|c|}
\hline \multicolumn{6}{|c|}{ ASIA: } \\
\hline & Name & Birth Year & Death Year & PLM & Region \\
\hline 1 & Xia Dynasty & 1994 B. C. E. & 1523 B. C. E. & 6.5 & $\begin{array}{l}\text { N. China } \\
\text { S. China }\end{array}$ \\
\hline 2 & Brihadratha (Magadha E..) & 1700 B. C. E. & 799 B. C. E. & 50 & India \\
\hline 3 & Shang Dynasty & 1523 B. C. E. & 1027 B. C. E. & 6.5 & N. China \\
\hline 4 & Kingdom of Colchis & 1250 B. C. E. & 725 B. C. E. & .06 & C. Asia \\
\hline 5 & Pradyota (Magadha E.) & 799 B. C. E. & 684 B. C. E. & .50 & India \\
\hline 6 & Shishunaga (Magadha E.) & 684 B. C. E. & 424 B. C. E. & .50 & India \\
\hline 7 & Scythians & 500 B.C.E. & 150 C. E. & 5 & $\begin{array}{c}\text { C. Asia } \\
\text { S. Russia. }\end{array}$ \\
\hline 8 & Zhou Dynasty & 403 B.C.E. & 221 B.C.E. & 5.5 & N. China \\
\hline 9 & Nanda Dyn. (Magadha E.) & 343 B. C. E. & 321 B. C. E. & 1.5 & India \\
\hline 10 & Mauryan Empire & 320 B.C.E. & 183 B.C.E. & 5 & India \\
\hline 11 & Qin Dynasty & 247 B. C. E. & 209 B. C. E. & 12 & $\begin{array}{l}\text { N. China } \\
\text { S. China }\end{array}$ \\
\hline 12 & Xiongnu & 210 B. C. E. & 155 C. E. & 4 & Mongolia \\
\hline 13 & Han Empire & 202 B.C.E. & 220 C. E. & 6 & $\begin{array}{l}\text { N. China, } \\
\text { S. China. }\end{array}$ \\
\hline 14 & Shungas & 183 B. C. E. & 73 B. C. E. & 1.5 & India \\
\hline 15 & Toucherans & 162 B. C. E & 230 C. E. & 2 & C. Asia \\
\hline 16 & Koguryo & 150 B. C. E. & 668 C. E. & 20 & Korean pen. \\
\hline 17 & Satavahanas Empire & 100 B.C.E. & 225 C. E. & 1 & India \\
\hline 18 & Shakas & 90 B. C. E. & 20 C. E. & 1.5 & India \\
\hline 19 & Kanva (Magadha E.) & 71 B. C. E. & 26 B. C. E. & .50 & India \\
\hline 20 & Kushan Empire & $50 \mathrm{~B}$ & E. & 6 & $\begin{array}{l}\text { C. Asia, } \\
\text { NW. India. }\end{array}$ \\
\hline 21 & Paekche & 18 B. C. E. & 668 C. E. & .06 & Korean pen. \\
\hline 22 & Funan & 1 C. E. & 630 C. E. & .20 & Cambodia \\
\hline 23 & Kaya & 42 C. E. & 562 & .03 & Korean pen. \\
\hline 24 & Xian-bi & 155 C. E. & 400 C. E. & 4 & Mongolia \\
\hline 25 & Three Kingdoms & 220 C. E. & 265 C. E. & 6.5 & China \\
\hline 26 & Ganga Dynasty & 250 C. E. & 1004 C. E. & .15 & India \\
\hline 27 & Jin (eastern) & 265 C. E. & 420 C. E. & 5 & S. China \\
\hline 28 & Vakatakas & 300 C. E. & 500 C. E. & 1.5 & India \\
\hline 29 & Sixteen Kingdoms & 302 C. E. & 589 C. E. & 6.5 & China \\
\hline 30 & Gupta Empire & 320 C. E. & 535 C. E. & 3.5 & India \\
\hline
\end{tabular}




\section{Appendix A (continued):}

\begin{tabular}{|c|c|c|c|c|c|}
\hline \multicolumn{6}{|c|}{ ASIA: } \\
\hline & Name & Birth Year & Death Year & PLM & Region \\
\hline 31 & Pallavas & 330 C. E. & 890 C. E. & 1 & S. India \\
\hline 32 & Hun Empire & 370 C. E. & 560 C. E. & 4 & $\begin{array}{l}\text { C. Asia, } \\
\text { Mongolia, } \\
\text { Balkans, } \\
\text { E. Europe, } \\
\text { S. Russia. }\end{array}$ \\
\hline 33 & Ruan Ruan & 440 C. E. & 550 C. E. & 6.5 & Mongolia \\
\hline 34 & Champa & 550 C. E. & 1145 C. E. & .10 & Korean pen. \\
\hline 35 & Dvaravati & 580 C. E. & 1080 C. E. & .10 & S. E. Asia \\
\hline 36 & Karluks/Oghuz & 552 C. E. & 1070 C. E. & 1 & C. Asia \\
\hline 37 & Siu Dynasty & 589 C. E. & 628 C. E. & 6.5 & $\begin{array}{l}\text { N. China } \\
\text { S. China }\end{array}$ \\
\hline 38 & Srivijaya Empire & 600 C. E. & 1200 C. E. & 47 & Indonesia \\
\hline 39 & T'ang Dynasty & 618 C. E. & 907 C. E. & 6.5 & $\begin{array}{l}\text { N. China } \\
\text { S. China }\end{array}$ \\
\hline 40 & Chenla & 630 C. E. & 802 C. E. & .20 & Cambodia \\
\hline 41 & Khazaria $^{\mathrm{j}}$ & 650 C. E. & 965 C. E. & .85 & $\begin{array}{c}\text { Asia } \\
\text { Caucasus }\end{array}$ \\
\hline 42 & Silla & 668 C. E. & 935 C. E. & .12 & Korean pen. \\
\hline 43 & Nanzhao & 729 C. E. & 902 C. E. & .39 & S. China \\
\hline 44 & Uighars & 745 C. E. & 840 C. E. & 1.5 & Mongolia \\
\hline 45 & Kingdom of Abkhaziac & 780 C. E. & 1008 C. E. & .05 & N. W. Asia \\
\hline 46 & Heian Civilization & 794 C. E. & 1185 C. E. & .37 & Japan \\
\hline 47 & Khmer Empire & 802 C. E. & 1432 C. E. & .20 & Cambodia \\
\hline 48 & Tahirids $^{\mathrm{m}}$ & 821 C. E. & 873 C. E. & 1.2 & N. E. Iran \\
\hline 49 & Bagan Dynasty & 849 C. E. & 1287 C. E. & .66 & Burma \\
\hline 50 & Kievan Rus ${ }^{c}$ & 860 C. E. & 1150 C. E. & .08 & N. W. Asia \\
\hline 51 & Saffarids $^{\mathrm{m}}$ & 873 C. E. & 900 C. E. & 2 & Eastern Iran \\
\hline 52 & Sinkiang & 900 C. E. & 1050 C. E. & 1 & N. W. China \\
\hline 53 & Qarakhanids $^{\mathrm{m}}$ & 900 C. E. & 1090 C. E. & 1.5 & C. Asia \\
\hline 54 & Khitan & 907 C. E. & 1124 C. E. & 1.5 & Mongolia \\
\hline 55 & Liao & 916 C. E. & 1125 C. E. & 2 & N. China \\
\hline 56 & Samanids $^{\mathrm{m}}$ & E. & 10 & 2 & $\begin{array}{l}\text { C. Asia } \\
\text { Iran. }\end{array}$ \\
\hline 57 & Koryo & 935 C. E. & 1392 C. E. & .15 & Korean pen. \\
\hline
\end{tabular}




\section{Appendix A (continued):}

\begin{tabular}{|c|c|c|c|c|c|}
\hline \multicolumn{6}{|c|}{ ASIA: } \\
\hline & Name & Birth Year & Death Year & PLM & Region \\
\hline 58 & Song Dynasty & 960 C. E. & 1279 C. E. & 6.5 & $\begin{array}{l}\text { N. China } \\
\text { S. China }\end{array}$ \\
\hline 59 & Airlangga & 991 C. E. & 1049 C. E. & .04 & Java \\
\hline 60 & Hoysala Empire $^{\mathrm{m}}$ & 1006 C. E. & 1346 C. E. & .30 & India \\
\hline 61 & Kingdom of Georgia $^{c}$ & 1008 C. E. & 1466 C. E. & .07 & C. Asia \\
\hline 62 & Naimans \& Keraits $^{c}$ & 1009 C. E. & 1300 C. E. & .40 & C. Asia \\
\hline 63 & Kalinga Dynasty & 1028 C. E. & 1434 C. E. & .25 & India \\
\hline 64 & Kediri & 1049 C. E. & 1290 C. E. & .02 & Java \\
\hline 65 & Singharasi & 1049 C. E. & 1290 C. E. & .02 & Java \\
\hline 66 & Jin (late) & 1115 C. E. & 1234 C. E. & 8 & N. China \\
\hline 67 & Ghurids $^{\mathrm{m}}$ & 1173 C. E. & 1215 C. E. & 3 & C. Asia \\
\hline 68 & Kamakura Period & 1185 C. E. & 1335 C. E. & .37 & Japan \\
\hline 69 & G. Horde/Mongols ${ }^{\mathrm{m}}$ & 1206 C. E. & 1502 C. E. & 33.2 & $\begin{array}{c}\text { C. Asia, } \\
\text { Turkestan, } \\
\text { Mongolia } \\
\text { Balkans, } \\
\text { E. Europe, } \\
\text { S. Russia. }\end{array}$ \\
\hline 70 & Sultanate of Delhi ${ }^{\mathrm{m}}$ & 1211 C. E. & 1398 C. E. & 1.5 & India \\
\hline 71 & Chaghatai Khanate & 1260 C. E. & 1324 C. E. & 2.2 & C. Asia \\
\hline 72 & Yuan Dynasty & 1279 C. E. & 1368 C. E. & 6.5 & $\begin{array}{l}\text { N. China } \\
\text { S. China }\end{array}$ \\
\hline 73 & Majapahit Empire & 1293 C. E. & 1500 C. E. & .13 & Java Isl. \\
\hline 74 & Ashikaga (Muachi) Period & 1335 C. E. & 1573 C. E. & .37 & Japan \\
\hline 75 & Vijayanagar Kingdom & 1336 C. E. & 1646 C. E. & .60 & S. India \\
\hline 76 & Bahmani Sultanate $^{\mathrm{m}}$ & 1347 C. E. & 1518 C. E. & .70 & India \\
\hline 77 & Ming Dynasty & 1368 C. E. & 1644 C. E. & 6.5 & $\begin{array}{l}\text { N. China } \\
\text { S. China }\end{array}$ \\
\hline 78 & Sharqi Dyn. (Jaunpur) ${ }^{\mathrm{m}}$ & 1394 C. E. & 1479 C. E. & .004 & India \\
\hline 79 & Timurids & 1401 C. E. & 1505 C. E. & 4 & C. Asia \\
\hline 80 & Sultanate of Melaka ${ }^{\mathrm{m}}$ & 1403 C. E. & 1511 C. E. & .002 & S. E. Asia \\
\hline 81 & Toungoo Dynasty & 1486 C. E. & 1752 C. E. & .66 & Burma \\
\hline 82 & Mughal Empire $^{\mathrm{m}}$ & 1526 C. E. & 1765 C. E. & 1.5 & India \\
\hline 83 & Sur Dynasty & 1540 C. E. & 1556 C. E. & .60 & India \\
\hline
\end{tabular}


Appendix A (continued):

\begin{tabular}{|l|l|l|l|l|l|}
\hline \multicolumn{5}{|c|}{ AMERICA: } \\
\hline & \multicolumn{1}{|c|}{ Name } & Birth Year & Death Year & PLM & \multicolumn{1}{|c|}{ Region } \\
\hline \hline 84 & Azuchi-Momoyama Period & 1573 C. E. & 1613 C. E. & .37 & Japan \\
\hline 85 & Tokugawa Period & 1613 C. E. & 1867 C. E. & .37 & Japan \\
\hline 86 & Qing & 1644 C. E. & 1911 C. E. & 12 & $\begin{array}{l}\text { N. China } \\
\text { S. China }\end{array}$ \\
\hline
\end{tabular}




\section{Appendix A (continued):}

\begin{tabular}{|c|c|c|c|c|c|}
\hline \multicolumn{6}{|c|}{ AMERICA: } \\
\hline & Name & Birth Year & Death Year & PLM & Region \\
\hline 1 & Olmecs & 1500 B. C. E. & 400 B. C. E. & .12 & G. of Mexico \\
\hline 2 & Chavin & 1200 B. C. E. & 200 B. C. E. & .06 & Andes \\
\hline 3 & Adena & 1000 B. C. E. & 100 C. E. & .08 & Mississippi $\triangle$ \\
\hline 4 & Nazca & 400 B. C. E. & 450 C. E. & .07 & Andes \\
\hline 5 & Kaminaljuyu \& Izapa & 300 B. C. E. & 300 C. E. & .07 & Guatemala \\
\hline 6 & Hopewell & 200 B. C. E. & 400 C. E. & .12 & Mississippi $\Delta$ \\
\hline 7 & Mochica & 1 C. E. & 650 C. E. & .06 & Andes \\
\hline 8 & Teotihuacan & 1 C. E. & 650 C. E. & .20 & $\begin{array}{c}\text { Mexico } \\
\text { Guatemala }\end{array}$ \\
\hline 9 & Mogollon & 150 C. E. & 1350 C. E. & .60 & S. W. America \\
\hline 10 & Classic Maya & 200 C. E. & 850 C. E. & .50 & Yucatan \\
\hline 11 & Monte Alban & 200 C. E. & 700 C. E. & .08 & Mexico \\
\hline 12 & Mesa Verde & 500 C. E. & 1300 C. E. & .08 & SW. America \\
\hline 13 & Huari \& Tiahuan. & 500 C. E. & 900 C. E. & .10 & Andes \\
\hline 14 & Anasazi & 500 C. E. & 1450 C. E. & .50 & S. W. America \\
\hline 15 & Mississippi Culture & 800 C. E. & 1500 C. E. & .12 & Mississippi $\Delta$ \\
\hline 16 & Chimu & 900 C. E. & 1476 C. E. & .06 & Andes \\
\hline 17 & Chaco Canyon & 900 C. E. & 1150 C. E. & .08 & SW. America \\
\hline 18 & Hohokam & 900 C. E. & 1400 C. E. & .08 & Mississippi $\Delta$ \\
\hline 19 & Toltecs & 900 C. E. & 1156 C. E. & .50 & Mexico \\
\hline 20 & Mayapan & 987 C. E. & 1446 C. E. & .30 & Yucatan \\
\hline 21 & Inca & 1463 C. E. & 1533 C. E. & .09 & Andes \\
\hline 22 & Aztecs & 1325 C. E. & 1519 C. E. & .90 & Mexico \\
\hline
\end{tabular}




\section{Appendix A (continued):}

\begin{tabular}{|c|c|c|c|c|c|}
\hline \multicolumn{6}{|c|}{ AFRICA: } \\
\hline & Name & Birth Year & Death Year & PLM & Region \\
\hline 1 & Old Kingdom & 2686 B. C. E. & 656 B. C. E. & 1 & Egypt \\
\hline 2 & Middle Kingdom & 2040 B.C.E. & 1786 B.C.E. & 1 & Egypt \\
\hline 3 & New Kingdom & 1552 B.C.E. & 1069 B.C.E. & 1 & Egypt \\
\hline 4 & Late Period & 1069 B. C. E. & 730 B. C. E. & 1 & Egypt \\
\hline 5 & Kushites & 730 B.C.E. & 656 B.C.E. & 1 & Egypt \\
\hline 6 & Saite & 668 B.C.E. & 525 B.C.E. & 1 & \\
\hline 7 & Ptolemaic Empire & 323 B.C.E. & 20 B.C.E. & 1 & $\begin{array}{c}\text { Egypt, } \\
\text { Isreal/Palestine }\end{array}$ \\
\hline 8 & Meroe & 295 B. C. E. & 320 C. E. & 59 & N. Africa \\
\hline 9 & Axum Empire & 270 C. E. & 960 C. E. & 1.11 & Ethiopia \\
\hline 10 & Nubian Kingdoms ${ }^{\mathrm{c}}$ & 320 C. E. & 1504 C. E. & 1.1 & NE. Africa \\
\hline 11 & Soninke Dynasty & 770 C. E. & 1240 C. E. & .25 & Ghana \\
\hline 12 & Rustamids $^{m}$ & 776 C. E. & 909 C. E. & .80 & N. W. Africa \\
\hline 13 & Idrisids & 789 C. E. & 906 C. E. & .45 & . \\
\hline 14 & Aghlabids & 800 C. E. & 909 C. E. & .16 & $"$ \\
\hline 15 & Takrur & 800 C. E. & 1285 C. E. & .07 & W. Africa \\
\hline 16 & Ethiopian Empire $^{\mathrm{c}}$ & 961 C. E. & 1450 C. E. & .20 & SusSah. Africa \\
\hline 17 & Almoravids $^{\mathrm{m}}$ & 1056 C. E. & 1147 C. E. & 1 & N. Africa \\
\hline 18 & Abyssiniac $^{c}$ & 1117 C. E. & 1974 C. E. & 1.1 & Ethiopia \\
\hline 19 & Almohadids $^{\mathrm{m}}$ & 1130 C.E. & 1269 C.E. & 1 & N. Africa \\
\hline 20 & Hafsids $^{\mathrm{m}}$ & 1229 C. E. & 1574 C. E. & 16 & N. W. Africa \\
\hline 21 & Mali $^{\mathrm{m}}$ & 1235 C. E. & 1400 C. E. & 1.1 & West Africa \\
\hline 22 & Zayyanids (Abd al-Wadid) ${ }^{\mathrm{m}}$ & 1236 C. E. & 1550 C. E. & 2 & N. W. Africa \\
\hline 23 & Marinids (Banu Marin) $)^{\mathrm{m}}$ & 1248 C. E. & 1548 C. E. & .60 & N. W. Africa \\
\hline 24 & Djolof Empire $^{\mathrm{m}}$ & 1350 C. E. & 1556 C. E. & .19 & SubSah. Africa \\
\hline 25 & Oyo Empire & 1400 C. E. & 1835. C. E. & .20 & W. Africa \\
\hline 26 & Songhai $^{\mathrm{m}}$ & 1464 C. E. & 1591 C. E. & 1.1 & West Africa \\
\hline 27 & Kongo $^{c}$ & 1490 C. E. & 1718 C. E. & .13 & Central Africa \\
\hline 28 & Bunyoro $^{c}$ & 1550 C. E. & 1850 C. E. & .15 & SubSah Africa. \\
\hline
\end{tabular}


Appendix B: Regions of the World and their Land Areas (in $\mathrm{km}^{2}$ )

\section{The Near East:}

Anatolia

770,760

Armenia

28,400

Iran

$1,636,000$

Israel

20,330

Mesopotamia

432,162

Palestinian Territories

6,000

Syria

184,050

The Eastern Mediterranean

200,000

\section{Central Asia:}

Afghanistan $\quad 647,500$

China (South) $\quad 4,663,205$

China (North) 4,663,205

India $\quad 2,229,892$

India (Northwest) $\quad 743,298$

Mongolia $\quad 1,564,116$

Pakistan $\quad 778,720$

Southern Russia $\quad 2,919,800$

Tajikistan $\quad 142,700$

Turkestan $\quad 1,190,900$

\section{Europe:}

Britain 241,590

Western Continental Europe 1,295,707

Central Continental Europe $\quad 765,457$

Eastern Continental Europe $\quad 553,699$

The Balkans $\quad 616,769$

Africa:

Egypt 995,450

N. Africa (Northeast exc. Egypt) $\quad 1,923,140$

N. Africa (West) 2,828,290

The Americas:

Yucatan $\quad 60,000$

Andes $\quad 60,000$ 
Guatemala

120,000

Mexico

200,000

Gulf of Mexico

150,000

Southwest America

70,000

Mississippi Delta

150,000 
Appendix C: Omitted Civilizations (due to autonomy, scale or data issues)

\begin{tabular}{|c|c|c|c|}
\hline \multicolumn{4}{|c|}{ MIDDLE EAST: } \\
\hline & Name & Notes & Region \\
\hline 1 & Anatolian Derebeyliks & $\begin{array}{c}\text { Scale } \\
\text { (Çaka Bey, Sökmenli, Artuklu, } \\
\text { Danişmend, Inaloğlu, Saruhan } \\
\text { Menteşe, Tekke, Saruhan } \\
\text { Saltuklu, Ramazanoğlu, Mengücek } \\
\text { Ertena, Aydin, etc.) }\end{array}$ & Anatolia \\
\hline 2 & Nicaea Empire & Byzantine principality & \\
\hline 3 & Sumerians & City-states until Sargon I unites Akkadian Emp. & Mesopotamia \\
\hline
\end{tabular}

\begin{tabular}{|c|c|c|c|}
\hline \multicolumn{4}{|c|}{ EUROPE: } \\
\hline & Name & Notes & Region \\
\hline 1 & Mycenaean Civilization & info n.a. & Balkan pen. \\
\hline 2 & Early Germanic tribes & $\begin{array}{l}\text { Chamavi, Marcomani, } \\
\text { Harii, Cherusci, } \\
\text { Vandals, etc. }\end{array}$ & N. C. Europe \\
\hline 3 & Genoans & scale & Italian pen. \\
\hline 4 & Venetians & $"$ & \\
\hline 5 & Medieval Germanic groups & $\begin{array}{l}\text { Bavarians, Thuringians, } \\
\text { Alemanni, Saxons, } \\
\text { Burgundians, Salians, etc. }\end{array}$ & N. C. Europe \\
\hline 6 & Peoples of the European Steppe & $\begin{array}{c}\text { Gepids, Sueves, } \\
\text { Rugians }\end{array}$ & $"$ \\
\hline 7 & Greek city-states & $\begin{array}{c}750 \text { B. C. E. - } 400 \text { B. C. E. } \\
\text { city-states } \\
\text { (Arcadia, Phocis, Messania, } \\
\text { Argolis, Attica, Laconia, } \\
\text { Locris, Epirus, Thessaly, } \\
\text { Achaea Aetolia, etc.) }\end{array}$ & Balkan pen. \\
\hline 8 & English Heptarchy Kingdoms & $\begin{array}{c}\text { scale, } \\
\text { (EastAnglia, Essex, } \\
\text { Kent, Mercia, } \\
\text { Northumbria, Sussex, } \\
\text { Wessex) }\end{array}$ & British Isl. \\
\hline
\end{tabular}


Appendix C: (continued)

\begin{tabular}{|c|c|c|c|}
\hline \multicolumn{4}{|c|}{ ASIA: } \\
\hline & Name & Notes & Region \\
\hline 1 & Asian Nomad Cultures & $\begin{array}{c}6000 \text { B. C. E. - } 500 \text { C. E. } \\
\text { info n. a. } \\
\text { (Andronovo, Srubnaya Cultures, } \\
\text { Kizil Kum, Kara Kum, } \\
\text { Pamris, Cimmerians, } \\
\text { Yuezhi, Massagatae, } \\
\text { Dahae, Alans, Hunas, etc.) }\end{array}$ & Central Asia \\
\hline 2 & Xixia & info n.a. & China \\
\hline 3 & Dai Vet & $"$ & 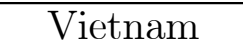 \\
\hline 4 & Chiao-chih & $"$ & $"$ \\
\hline 5 & Chiu-chen & $"$ & $"$ \\
\hline 6 & Lan Chang & $"$ & Burma \\
\hline 7 & Pegu & $"$ & $"$ \\
\hline 8 & Chiengmai & $"$ & $"$ \\
\hline 9 & Arakan & $"$ & " \\
\hline 10 & Ahom & $"$ & $"$ \\
\hline 11 & Sultanate of Sulu & $\begin{array}{c}\text { info n.a. } \\
\text { 1450C.E. - 1899C.E. }\end{array}$ & Indonesia \\
\hline 12 & Sultanate of Macassar-Gowa & info n.a. & $"$ \\
\hline 13 & Angkor & $"$ & Thailand \\
\hline 14 & Silla & $"$ & \\
\hline 15 & Gondwana & $"$ & India \\
\hline 16 & Telingana & $"$ & $"$ \\
\hline 17 & Gujarat & $"$ & $"$ \\
\hline 18 & Orissa & $"$ & $"$ \\
\hline 19 & Malwa & $"$ & $"$ \\
\hline 20 & Chin & $"$ & China \\
\hline 21 & Yen & $"$ & 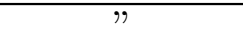 \\
\hline 22 & Cheng & $"$ & $"$ \\
\hline 23 & Sogdiana & Tang Dynasty suzeranity & $"$ \\
\hline 24 & Uighur Turks & Tang Dynasty auxiallry & 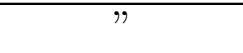 \\
\hline 25 & Sung & info n.a. & S. China \\
\hline 26 & Nan Chao (Taj) & " & \\
\hline 27 & Gurjarat & $"$ & India \\
\hline 28 & Gauda & $"$ & \\
\hline
\end{tabular}


Appendix C: (continued)

\begin{tabular}{|c|c|c|c|}
\hline \multicolumn{4}{|c|}{ ASIA: } \\
\hline & Name & Notes & Region \\
\hline 29 & Lanna & $"$ & \\
\hline 30 & Annam & $"$ & $"$ \\
\hline 31 & Gangga Negara & $"$ & Malaysia \\
\hline 32 & Langkasuka & $"$ & 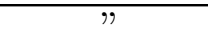 \\
\hline 33 & Pan Pan & $"$ & $"$ \\
\hline 34 & Kedah Sultanate & 1136 C. E. - present & $"$ \\
\hline 35 & Johor Sultanate & 1528 C. E. - 1899 C. E. & $"$ \\
\hline 36 & Hsiung-nu Empire & info n.a. & $"$ \\
\hline 37 & Yadava Dynasty & vassals of Sul. of Delhi & India \\
\hline 38 & Pandya Dynasty & info n.a. & \\
\hline 39 & Calukya Dynasty & info n.a. & \\
\hline 40 & Kanva & Magadha Emp. dynasty & India \\
\hline 41 & Indus Civilization & 2500 B C. E. - end date uncertain & S. E. Asia \\
\hline 42 & Pre-Mauryan Indian civ. & $\begin{array}{c}\text { info n. a. } \\
\text { Pancalas, Kashis, } \\
\text { Kurus, Vitihotras }\end{array}$ & S. India \\
\hline
\end{tabular}

\begin{tabular}{|c|c|c|c|}
\hline \multicolumn{4}{|c|}{ AMERICA: } \\
\hline & Name & Notes & Region \\
\hline 1 & Native American Tribes & $\begin{array}{c}\text { scale, info n.a. } \\
\text { 500 C.E.-1500 C.E. } \\
\text { (Nootka, Chinook, Yurok, Pomo, } \\
\text { Kaska, Inuit, Sioux, Cheyenne, } \\
\text { Arapaho, Apache, Cherokee, } \\
\text { Algonkin Nations, etc.) }\end{array}$ & N. America \\
\hline 2 & Zapotec & info n.a. & Meso America \\
\hline 3 & Mixtec & $"$ & \\
\hline 4 & Tarascan & $"$ & $"$ \\
\hline
\end{tabular}


Appendix C: (continued)

\begin{tabular}{|c|l|c|c|}
\hline \multicolumn{4}{|l|}{ AFRICA: } \\
\hline 1 & Name & Notes & Region \\
\hline 1 & Lunda Empire & info n.a. & SubSah. Africa \\
\hline 2 & Borno Kanem & " & $"$ \\
\hline 3 & Great Zimbabwe & city-state & no settlement \\
\hline 4 & Banu Hilal & $\begin{array}{c}\text { N. W. Africa } \\
\text { nomadic Bedouin tribe }\end{array}$ \\
\hline 5 & Zirids & $\begin{array}{c}\text { did not gain full control } \\
\text { splinter from Fatimids }\end{array}$ & $"$ \\
\hline
\end{tabular}

